\title{
Impact of Gobi desert dust on aerosol chemistry of Xi'an, inland China during spring 2009: differences in composition and size distribution between the urban ground surface and the mountain atmosphere
}

\author{
G. H. Wang ${ }^{1}$, B. H. Zhou ${ }^{2,3}$, C. L. Cheng ${ }^{1}$, J. J. Cao ${ }^{1}$, J. J. Li ${ }^{1}$, J. J. Meng ${ }^{3}$, J. Tao ${ }^{4}$, R. J. Zhang ${ }^{5}$, and P. Q. Fu ${ }^{6}$ \\ ${ }^{1}$ Key Lab of Aerosol Science \& Technology, State Key Laboratory of Loess and Quaternary Geology, Institute of Earth \\ Environment, Chinese Academy of Sciences, Xi' an 710075, China \\ ${ }^{2}$ School of Environmental and Municipal Engineering, Xi'an University of Architecture and Technology, Xi'an 710055, \\ China \\ ${ }^{3}$ Department of Geographical Science and Environmental Engineering, Baoji University of Arts and Sciences, Baoji 721013, \\ China \\ ${ }^{4}$ South China Institute of Environmental Sciences, China Ministry of Environmental Protection, Guangzhou 510655, China \\ ${ }^{5}$ Key Laboratory of Regional Climate-Environment for Temperate East Asia, Institute of Atmospheric Physics, Chinese \\ Academy of Sciences, Beijing 100029, China \\ ${ }^{6}$ Institute of Atmospheric Physics, Chinese Academy of Sciences, Beijing 100029, China
}

Correspondence to: G. H. Wang (wanggh@ieecas.cn, gehuiwang@yahoo.com.cn)

Received: 30 June 2012 - Published in Atmos. Chem. Phys. Discuss.: 21 August 2012

Revised: 27 November 2012 - Accepted: 19 December 2012 - Published: 22 January 2013

\begin{abstract}
Composition and size distribution of atmospheric aerosols from Xi'an city ( $\sim 400 \mathrm{~m}$, altitude) in inland China during the spring of 2009 including a massive dust event on 24 April were measured and compared with a parallel measurement at the summit $(2060 \mathrm{~m}$, altitude) of Mt. Hua, an alpine site nearby Xi'an. EC (elemental carbon), OC (organic carbon) and major ions in the city were 2-22 times higher than those on the mountaintop during the whole sampling period. Compared to that in the non-dust period a sharp increase in OC was observed at both sites during the dust period, which was mainly caused by an input of biogenic organics from the Gobi desert. However, adsorption/heterogeneous reaction of gaseous organics with dust was another important source of OC in the urban, contributing $22 \%$ of OC in the dust event. In contrast to the mountain atmosphere where fine particles were less acidic when dust was present, the urban fine particles became more acidic in the dust event than in the non-dust event, mainly due to enhanced heterogeneous formation of nitrate and diluted $\mathrm{NH}_{3} \cdot \mathrm{Cl}^{-}$and $\mathrm{NO}_{3}^{-}$in the urban air during the dust event significantly shifted toward coarse particles. Such redistributions were further pronounced on
\end{abstract}

the mountaintop when dust was present, resulting in both ions almost entirely staying in coarse particles. On the contrary, no significant spatial difference in size distribution of $\mathrm{SO}_{4}^{2-}$ was found between the urban ground surface and the mountain atmosphere, which dominated in the fine mode $(<2.1 \mu \mathrm{m})$ during the nonevent and comparably distributed in the fine $(<2.1 \mu \mathrm{m})$ and coarse $(>2.1 \mu \mathrm{m})$ modes during the dust event.

\section{Introduction}

Dust is a major source of particulate matter to the atmosphere. Global annual mean burden of aerosol dust is about $20 \mathrm{Tg}( \pm 40 \%)$ (McNaughton et al., 2009). Dust can influence the solar radiation by directly absorbing/reflecting sunlight and indirectly acting as cloud condensation nuclei (CCN) or ice nuclei (IN) (Jacobson, 2001; Manktelow et al., 2010; McNaughton et al., 2009; Seinfeld et al., 2004). Furthermore, dusts can cause adverse health effects since they can deposit into human respiratory tract and become more 
toxic after mixing with pollutants by absorption and reaction (Griffin et al., 2001). Gobi deserts located in south Mongolia and north China are one of the major source regions of East Asian dust (Arimoto et al., 2006; Sullivian et al., 2007). In each spring and early summer surface dust in Gobi desert region is brought about by front cold systems and the Mongolian cyclonic depression and transported into the downwind areas including North America (Leaitch et al., 2009; Seinfeld et al., 2004; VanCuren and Cahill, 2002). During transport mineral dust can internally mix with secondary compounds such as ammonium sulfate, ammonium nitrate, carboxylic acids, nitrogen-containing organics and sea salt by coagulation, cloud-processing and heterogeneous reactions (Geng et al., 2009; Seinfeld et al., 2004; Sullivan et al., 2009a; Tobo et al., 2010; Wang et al., 2012a; Zamora et al., 2011; Zhang et al., 2003). These processes modify the physicochemical properties of the airborne aerosols containing dust, exerting a significant impact on the downwind atmospheric environment (Dillner et al., 2006).

Field measurements of the Gobi dust have been performed at many sites from the source region in northern/northwestern China to North America. However, simultaneous observation for dust-laden aerosols between the boundary layer and the free troposphere has been conducted only in the Asian continental outflow region such as the ACE-Asia 2001 in Northwest Pacific (Huebert et al., 2003; Seinfeld et al., 2004; Simoneit et al., 2004a, b) and the INTEX-2006 in Northeast America (Dunlea et al., 2009; Peltier et al., 2008; van Donkelaar et al., 2008), but there is no such a simultaneous measurement conducted in inland China. Located in central China, Guanzhong Basin is one of the most polluted regions in the world, where the annual average level of fine particles was more than $80 \mu \mathrm{g} \mathrm{m}^{-3}$ in 2001-2006 (van Donkelaar et al., 2010; Wang et al., 2006a, b, 2010). In the spring of 2009, an intensive observation of atmospheric aerosols was performed simultaneously in $\mathrm{Xi}$ ' an $\left(109^{\circ} 39^{\prime} \mathrm{E}, 34^{\circ} 45^{\prime} \mathrm{N}\right)$, Mt. Hua $\left(110^{\circ} 06^{\prime} \mathrm{E}, 34^{\circ} 35^{\prime} \mathrm{N}\right)$ and Mt. Tai $\left(117^{\circ} 06^{\prime} \mathrm{E}, 36^{\circ} 15^{\prime} \mathrm{N}\right)$, which are respectively situated in Guanzhong Basin, inland China and North China Plain, east coastal China (see Fig. 1 for the locations), to identify the similarity and difference in chemical composition and size distribution of aerosols between the ground surface and the free troposphere (Wang et al., 2011c, 2012b). During the sampling period a massive dust storm originating from the Gobi desert simultaneously occurred at the three sites. In our previous papers EC(elemental carbon), OC (organic carbon), inorganic ions and organic compounds in $\mathrm{PM}_{10}$ of Mt. Hua and Mt. Tai have been measured to recognize the horizontal differences in aerosol chemistry between the two mountain areas (Wang et al., 2011c, 2012b). We found Gobi desert plant is the major source of organic aerosols that resulted in a sharp increase in $\mathrm{OC}$ at the two alpine sites when dust was present (Wang et al., 2012b). In the current study, we further investigate the difference in aerosol chemistry between the boundary layer and the free

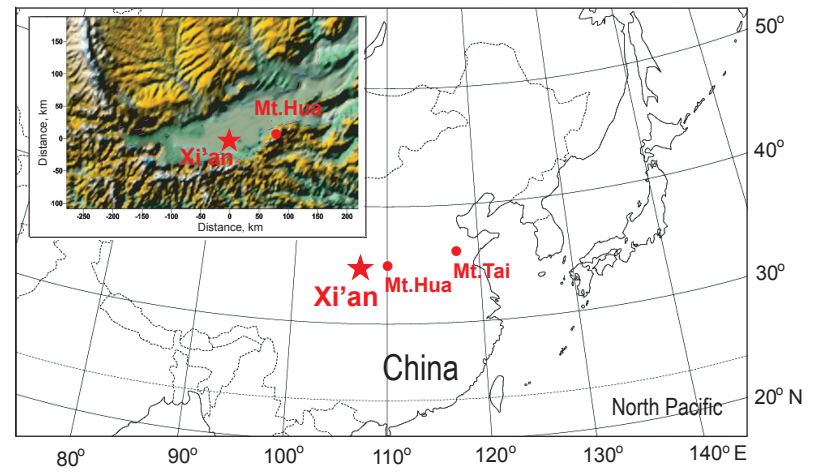

Fig. 1. A map description for Xi' an city and Mt. Hua in Guanzhong Basin, central China (inserted figure showing the topography of Guanzhong Basin).

troposphere over Guanzhong Basin, central China by a simultaneous observation of aerosols in Xi' an and Mt. Hua. Both Xi' an city and Mt. Hua are located within the same region, i.e., Guanzhong Basin, with a distance $\sim 80 \mathrm{~km}$. A previous study compared the aerosol loading and precipitation amount between Xi' an and Mt. Hua in the past fifty years and found that the decreasing precipitation in Mt. Hua is deeply related to the increasing air pollution over Guanzhong Basin (Rosenfeld et al., 2007). Here, we first characterize composition and size distribution of springtime airborne particles in $\mathrm{Xi}^{\prime}$ an, and then compare these urban results with the previously published results of Mt. Hua. The current study demonstrated that dust storm has different effects on the chemical properties of aerosols from the ground surface $(\sim 400 \mathrm{~m}$ a.s.l.) and the mountaintop troposphere (2060 $\mathrm{m}$ a.s.l.), resulting in acidity of fine particles increasing on the urban ground surface and decreasing in the mountaintop atmosphere when dust was present.

\section{Experimental section}

\subsection{Collection of $\mathrm{PM}_{10}$ and size-segregated particles}

Xi' an city is situated in Guanzhong Basin, a semi-arid region in central China (Fig. 1). $\mathrm{PM}_{10}$ and 9-stage size-segregated samples were simultaneously collected on the rooftop $(10 \mathrm{~m}$ above the ground) of a three-story building at Institute of Earth Environment in the urban area of Xi'an. The $\mathrm{PM}_{10}$ sample was collected on a day/night basis at an airflow rate of $100 \mathrm{~L} \mathrm{~min}^{-1}$, while the size-segregated samples were collected for 4 days in each set at an airflow rate of $28 \mathrm{~L} \mathrm{~min}^{-1}$ with 9 size bins as $<0.4,0.4-0.7,0.7-1.1,1.1-2.1,2.1-3.3$, $3.3-4.7,4.7-5.8,5.8-9.0$ and $>9.0 \mu \mathrm{m}$, respectively. The sampling lasted for one month from 25 March to 25 April 2009. All the samples were collected onto pre-combusted $\left(450^{\circ} \mathrm{C}\right.$ for $\left.8 \mathrm{~h}\right)$ quartz fiber filters. The airflow rates of the two samplers were calibrated before and after the sampling 
to ensure the instruments working at the specified flow rates. After sampling, the filter was sealed in an aluminum foil bag and stored at $-20^{\circ} \mathrm{C}$ before analysis. The particle mass on the filter was gravimetrically measured using a microelectronic balance (Mettler M3, Swiss) with a sensitivity limit of $10 \mu \mathrm{g}$ after a 24-h equilibration inside a chamber $\left(\mathrm{RH}=50 \pm 10 \%, T=23-25^{\circ} \mathrm{C}\right)$. Field blank samples were collected respectively in the beginning and the end of the sampling campaign by mounting a filter onto the sampler for about 10 min without sucking any air. No significant contaminants were found in the blank sample except sulfate and nitrate, which are less than $2 \%$ of the mass in the real samples. Data reported here were all corrected by the field blanks.

During the sampling period, a moderate dust storm (Named as DS I, hereinafter) originating from the Gobi desert reached Xi' an on 20 April, four days later a massive dust storm (Named as DS II, hereinafter), which also originated from the Gobi desert, arrived in Xi' an (on 24 April). Both episodes also simultaneously occurred at Mt. Hua, $80 \mathrm{~km}$ east to the city (Fig. 1). During the second event, the $\mathrm{PM}_{10}$ sampling duration was changed into $3-6 \mathrm{~h}$ depending on the particle loading, while the size-segregated sampling duration was changed into one day.

\subsection{Sample analysis}

\subsubsection{Inorganic ions, water-soluble organic (WSOC) and inorganic carbon (WSIC), and water-soluble organic nitrogen (WSON)}

One fourth of the filter was cut into pieces $\left(\sim 0.1 \mathrm{~cm}^{2}\right)$ and extracted with $5 \mathrm{~mL}$ Milli-Q pure water under sonication for three times in each, subsequently, combining the extractants for the final analysis. One part of the combined waterextracts was determined for inorganic ions using Dionex6000 ion chromatography after a measurement of $\mathrm{pH}$ value using a $\mathrm{pH}$ meter (HANNA HI8424 $\mathrm{pH}$ meter, US) at an ambient temperature of $25^{\circ} \mathrm{C}$. Another part of the water-extracts was determined for water-soluble organic carbon (WSOC), water-soluble inorganic carbon (WSIC) and water-soluble total nitrogen (WSTN) using Shimadzu 5000 TOC/N Analyzer. The detailed analysis methods for inorganic ions, WSOC and WSTN can be found elsewhere (Wang et al., 2010). $\mathrm{NO}_{3}^{-}$and $\mathrm{NH}_{4}^{+}$are the major water-soluble inorganic nitrogen (WSIN) species in airborne particles, thus the difference between WSTN and WSIN is defined as water-soluble organic nitrogen (WSON). It is worth noting that there are possibly some problems associated with sonication, which include mechanical rupture of particles that might lead to greater ion release and particle solubility than would naturally occur, although sonication is a common method for aerosol measurement.

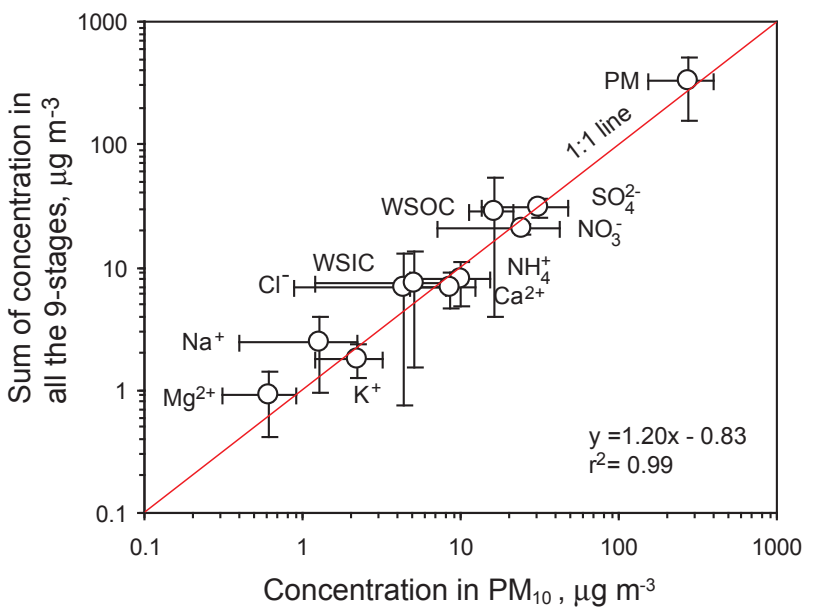

Fig. 2. Intercomparison of components measured by the $\mathrm{PM}_{10}$ sampler and the 9-stage sampler during the campaign.

\subsubsection{Organic carbon (OC) and elemental carbon (EC)}

OC and EC in the $\mathrm{PM}_{10}$ samples were measured by a DRI Model 2001 Carbon Carbon Analyzer using the Interagency Monitoring of Protected Visual Environments (IMPROVE) thermal/optical reflectance (TOR) protocol (Chow et al., 2004, 2007). Briefly, a size of $0.53 \mathrm{~cm}^{2}$ filter was put in a quartz boat inside the analyzer and progressively heated to temperatures of $120^{\circ}, 250^{\circ}, 450^{\circ}$, and $550^{\circ}$ in a nonoxidizing helium $(\mathrm{He})$ atmosphere, and $550^{\circ}, 700^{\circ}$, and $800^{\circ}$ in an oxidizing atmosphere containing $2 \%$ oxygen in helium.

An intercomparison was made for the $\mathrm{PM}_{10}$ and the sizeresolved samplers. As shown in Fig. 2, a linear correlation was observed for particle mass (PM) and major species measured by the two samplers with a slope close to unity, indicating a good agreement between the two data sets. A parallel observation was performed at the summit ( $2060 \mathrm{~m}$ a.s.l.) of Mt. Hua using the same sampling instruments; the related data have been published elsewhere (Wang et al., 2011c, 2012b) and are cited here to investigate the difference in composition and size distribution between the urban ground surface and the mountaintop troposphere.

Aerosols were simultaneously collected at the summit of Mt. Hua using a sampling protocol same as that in Xi'an, except for $\mathrm{PM}_{10}$ during the non-dust period, which was collected for $24 \mathrm{~h}$ in each in order to obtain enough materials. As seen in Fig. 3, air masses reaching Xi' an and Mt. Hua during the DS II period originated from the same Gobi regions and transported via same pathways before simultaneously arriving at the two sites, resulting in particles in the DS II event presenting similar levels of loading $\left(\mathrm{PM}_{10}\right.$ in $\mathrm{Xi}$ ' an and Mt. Hua were $589 \pm 273$ and $506 \pm 303 \mu \mathrm{g} \mathrm{m}^{-3}$, respectively) with a same size distribution pattern in Xi' an and Mt. Hua (see details in Sect. 3.2). Trehalose, a metabolism product of biota in the Gobi desert (Wang et al., 2012b), 
Table 1. Concentrations of water-soluble species, elemental carbon (EC) and organic carbon (OC) of PM 10 during the spring 2009 in Xi' an, China, $\mu \mathrm{g} \mathrm{m}^{-3}$.

\begin{tabular}{|c|c|c|c|c|}
\hline & \multicolumn{2}{|c|}{ Non-dust storm period } & \multicolumn{2}{|c|}{ Dust storm period } \\
\hline & Daytime $(N=29)$ & Nighttime $(N=31)$ & $\operatorname{DS} \mathrm{I}(N=1)$ & $\operatorname{DS} \mathrm{II}(N=3)$ \\
\hline $\mathrm{PM}_{10}$ & $250 \pm 79(58-420)$ & $263 \pm 90(110-415)$ & 527 & $589 \pm 273(358-890)$ \\
\hline $\mathrm{pH}^{\mathrm{a}}$ & $-0.3 \pm 0.3(-1.1-0.2)$ & $-0.4 \pm 0.3(-1.0-0.1)$ & 0.4 & $0.0 \pm 0.1(-0.1-0.1)$ \\
\hline $\mathrm{F}^{-}$ & $0.5 \pm 0.3(0.0-1.3)$ & $0.5 \pm 0.3(0.1-1.1)$ & 0.3 & $0.4 \pm 0.2(0.1-0.6)$ \\
\hline $\mathrm{Cl}^{-}$ & $2.9 \pm 2.5(0.4-11)$ & $6.1 \pm 3.9(0.6-15)$ & 4.1 & $3 \pm 1.8(1.1-4.7)$ \\
\hline $\mathrm{NO}_{3}^{-}$ & $27 \pm 17(4.0-72)$ & $24 \pm 18(4.0-66)$ & 6.0 & $11 \pm 7.0(5.7-19)$ \\
\hline $\mathrm{SO}_{4}^{2-}$ & $33 \pm 17(8.0-88)$ & $30 \pm 18(8.9-82)$ & 17 & $17 \pm 10(7.5-27)$ \\
\hline $\mathrm{Na}^{+}$ & $1.1 \pm 0.6(0.1-3.1)$ & $1.3 \pm 0.8(0.2-3.9)$ & 5.0 & $2.1 \pm 1.5(0.4-3.4)$ \\
\hline $\mathrm{NH}_{4}^{+}$ & $11 \pm 5.0(2.0-24)$ & $10 \pm 5.2(2.1-23)$ & 1.8 & $3.9 \pm 4.0(1.6-8.6)$ \\
\hline $\mathrm{K}^{+}$ & $2.1 \pm 1.0(0.6-5.3)$ & $2.4 \pm 1.0(1.1-4.8)$ & 1.4 & $1.3 \pm 0.5(0.8-1.8)$ \\
\hline $\mathrm{Mg}^{2+}$ & $0.5 \pm 0.2(0.1-1.1)$ & $0.6 \pm 0.3(0.1-1.2)$ & 1.1 & $1.3 \pm 0.6(0.9-1.9)$ \\
\hline $\mathrm{Ca}^{2+}$ & $8.5 \pm 3.5(0.8-14)$ & $8.0 \pm 3.8(0.9-16)$ & 16 & $13 \pm 2.7(11-16)$ \\
\hline WSOC $^{b}$ & $16 \pm 4.4(4.7-25)$ & $17 \pm 5.3(8.1-29)$ & 6.4 & $16 \pm 5.6(13-23)$ \\
\hline WSIC $^{b}$ & $4.6 \pm 2.7(1.2-11)$ & $4.7 \pm 3.2(1.3-14)$ & 13 & $13 \pm 10(3.8-24)$ \\
\hline WSTN $^{\mathrm{c}}$ & $20 \pm 7.3(11-42)$ & $20 \pm 7.1(11-39)$ & 11 & $24 \pm 7.0(16-31)$ \\
\hline WSON $^{\mathrm{c}}$ & $5.6 \pm 1.1(3.8-8.1)$ & $6.5 \pm 3.4(3.7-22)$ & 8.1 & $19 \pm 12(5.5-28)$ \\
\hline $\mathrm{EC}$ & $10 \pm 4.8(2.6-23)$ & $14 \pm 7.5(4.9-29)$ & 5.5 & $5.2 \pm 2.9(2.3-8.1)$ \\
\hline OC & $23 \pm 7.4(7.9-38)$ & $28 \pm 12(12-67)$ & 29 & $35 \pm 12(21-43)$ \\
\hline OC/EC & $2.5 \pm 0.6(1.6-4.7)$ & $2.3 \pm 0.7(1.5-4.5)$ & 5.3 & $7.5 \pm 2.2(5.0-9.1)$ \\
\hline WSOC/OC & $0.7 \pm 0.2(0.4-0.9)$ & $0.6 \pm 0.2(0.3-0.9)$ & 0.2 & $0.5 \pm 0.1(0.3-0.6)$ \\
\hline WSON/WSTN & $0.3 \pm 0.2(0.1-0.7)$ & $0.4 \pm 0.2(0.1-0.8)$ & 0.7 & $0.8 \pm 0.3(0.3-0.9)$ \\
\hline
\end{tabular}

showed comparable concentrations in Xi' an and Mt. Hua in the occurrence of the DS II event. Therefore, we believe that both sites were dominated by a same air mass during the DS II episode and differences in chemical compositions of the dust samples from Xi' an and Mt. Hua in the dust event were mostly caused by adsorption/reaction of the lowland pollutants with dust.

\section{Results and discussion}

\subsection{Chemical composition}

\subsubsection{Chemical composition of $\mathrm{PM}_{10}$ in Xi'an during the non-dust and dust episodes}

Temporal variation of $\mathrm{PM}_{10}$ is presented in Fig. 4, and the chemical component concentrations are summarized in Table $1 . \mathrm{PM}_{10}$ ranged from 58 to $420 \mu \mathrm{g} \mathrm{m}^{-3}$ in the nonevent time with EC and OC as high as 29 and $67 \mu \mathrm{g} \mathrm{m}^{-3}$, respectively, suggesting a high loading of pollutants in the city. As seen in Table 1, there is no significant difference in the concentrations between day and night during the non-dust storm period, which is mostly due to the stagnant meteorological conditions within the basin-like region. The daytime and nighttime $\mathrm{OC} / \mathrm{EC}$ ratios were $2.5 \pm 0.6$ and $2.3 \pm 0.7$ during the nonevent period, respectively. Relative abundance of water-soluble organic nitrogen (WSON) to water-soluble total nitrogen (WSTN) were $0.3 \pm 0.2$ and $0.4 \pm 0.2$ in the day and night samples during the non-dust storm period (Table 1), suggesting that inorganic nitrogen compounds, i.e., nitrate and ammonium, are the major nitrogen-containing species in the atmosphere during the non-dust event period. However, WSON/WSTN ratios increased to 0.7 and $0.8 \pm 0.3$ in the DS I and DS II episodes, respectively, indicating that organic nitrogen species during the events were more abundant than ammonium and nitrate. The absolute concentration of WSON was 8.1 and $19 \pm 12 \mu \mathrm{g} \mathrm{m}^{-3}$ during the two events, respectively, which is 2-5 times higher than that in the nonevent especially in the DS II event. Such an enhancement of WSON was also observed in Miami and Barbados (Zamora et al., 2011) and Eastern Mediterranean (Violaki and Mihalopoulos, 2010) when Saharan dust presented. Compared to that of Saharan dust, the level of WSON in the Xi' an dust is much higher. Such a phenomenon is consistent with the level of WSON in Chinese rain, which was found to be $111 \mathrm{~mol} \mathrm{~L}^{-1}$ at 15 Chinese rural, suburb and urban sites and much higher than other locations in the world (Zhang et al., 2008). The abundant WSON in Xi' an during the dust events indicates that WSON emission and/or chemistry in Guanzhong Basin is probably different from other 
(a) Non-dust event, Xi'an (03/25-04/25,2009)

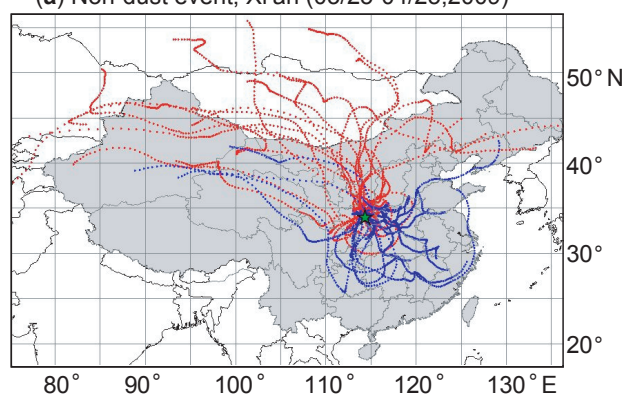

(b) Non-dust event, Mt. Hua (03/25-04/25,2009)

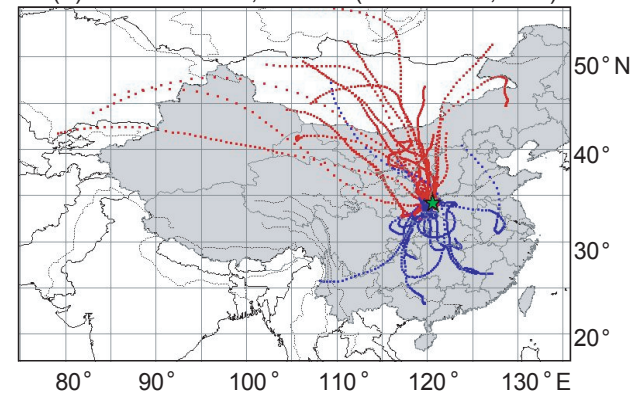

(c) DS II (04/24/2009) (Red: Xi'an; Blue:Mt. Hua)

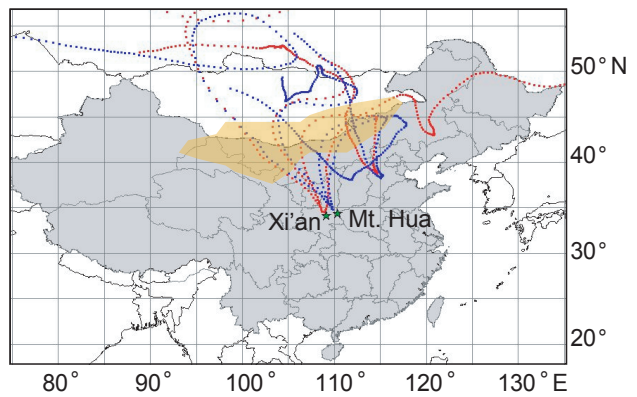

Fig. 3. Backward trajectories of air masses reaching Xi' an and Mt. Hua during (a, b) the non-dust event ( $24 \mathrm{~h}$ interval, air masses transported from northerly are in red while those from southerly are in blue) and (c) the dust storm event II (DS II, 00:00-18:00, local time, 6 h interval, air masses reaching Xi' an are in red while those reaching Mt. Hua are in blue) (The yellowish shadow in (c) is the Gobi desert region).

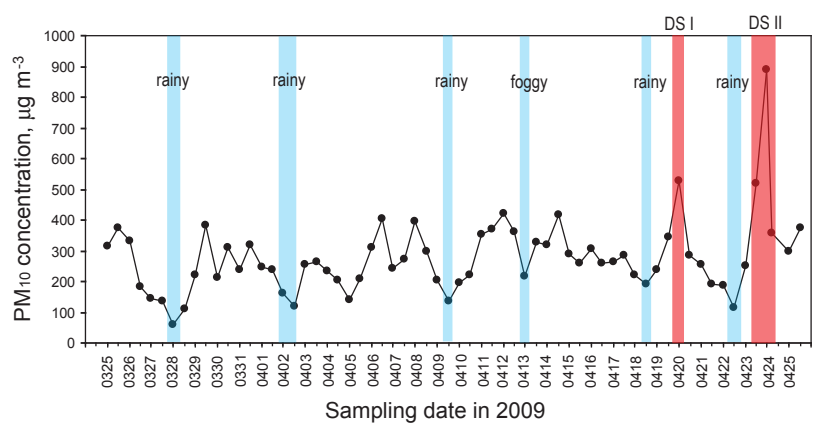

Fig. 4. Temporal variation of $\mathrm{PM}_{10}$ in $\mathrm{Xi}$ ' an during the spring of 2009 (DS I and DS II in red color represent the two dust storm events occurring on 20 and 24 April, respectively).

regions in the world, which warrants a further exploration. In addition, the WSON level is higher in the dust event than in the non-dust period, probably due to an additional WSON source upwind that was not present in the non-dust periods. Mass closure analysis further showed that the sum of total inorganic ions, EC and organic matter (OM) accounted for over $70 \%$ of $\mathrm{PM}_{10}$ mass with the remaining being insoluble mineral dust (Fig. 5a, b), in contrast to that in the dust periods, which was only $23 \%$ and $24 \%$ in the DS I and DS II events, respectively (Fig. 5c, d).
(I) Non-dust period
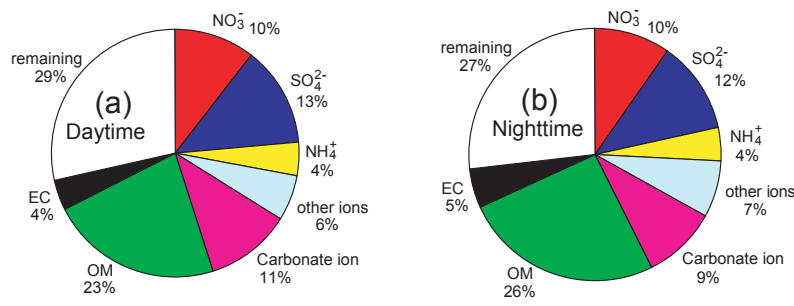

(II) Dust storm period
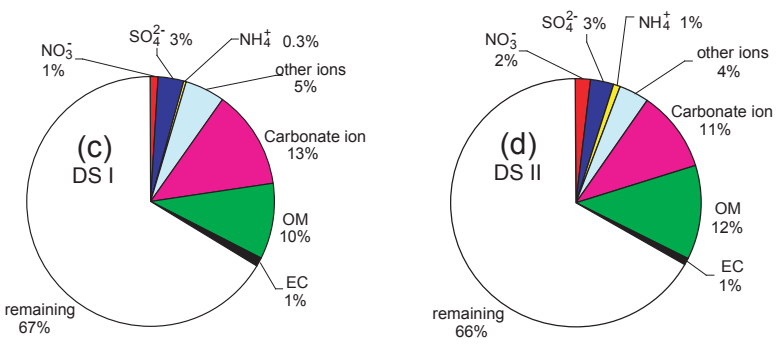

Fig. 5. Mass closure of $\mathrm{PM}_{10}$ during the sampling periods (OM: organic matter $=\mathrm{OC} \times 1.6$ ). 
(a) Non-dust period

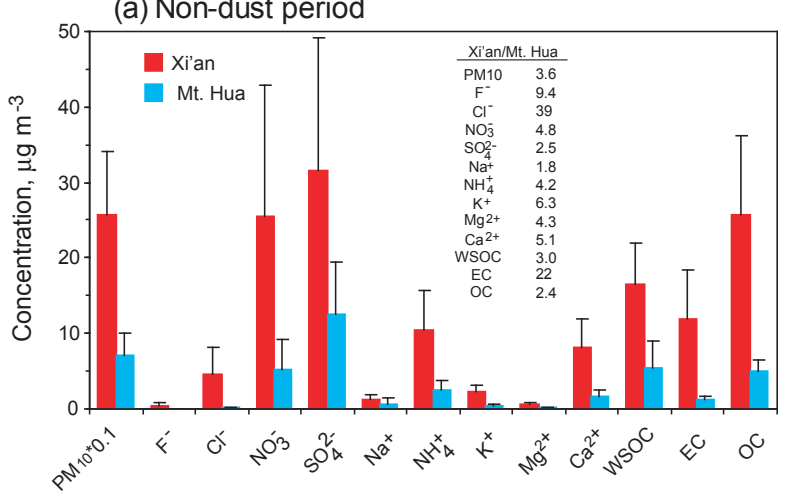

(b) DS II (April 24, 2009)

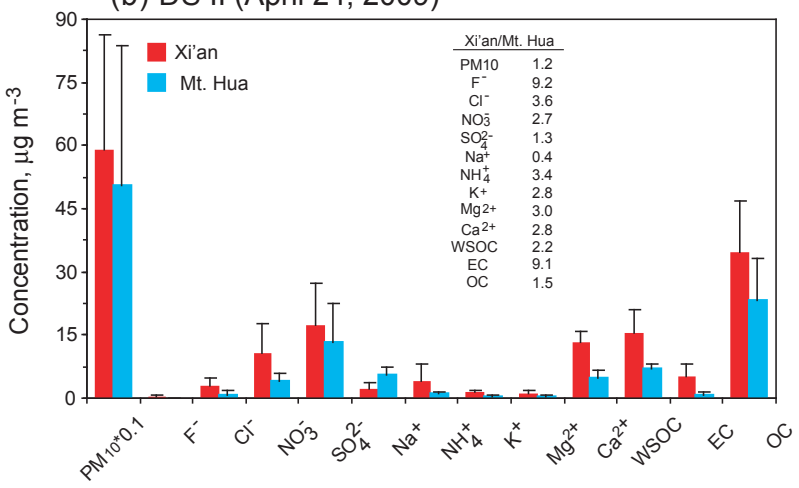

Fig. 6. Differences in concentrations of components of $\mathrm{PM}_{10}$ from $\mathrm{Xi}$ ' an and Mt. Hua during the non-dust and dust storm periods (inserted numbers are the concentration ratios of Xi' an to Mt. Hua).

\subsubsection{Difference in chemical composition between Xi'an and Mt. Hua}

Figure 6 compares differences in the concentrations of major aerosols in Xi' an with those in Mt. Hua during the same periods. In the nonevent time $\mathrm{PM}_{10}$ in $\mathrm{Xi}$ ' an was 3.6 times that in Mt. Hua (Fig. 6a), and the most abundant species in the $\mathrm{PM}_{10}$ samples at both sites was $\mathrm{SO}_{4}^{2-}$, followed by $\mathrm{NO}_{3}^{-}$, OC and $\mathrm{NH}_{4}^{+}$. On the contrary, in the DS II time the most abundant species in the $\mathrm{PM}_{10}$ samples at both sites was OC, followed by $\mathrm{SO}_{4}^{2-}, \mathrm{Ca}^{2+}$ and $\mathrm{NO}_{3}^{-}$(Fig. 6b). Our previous study (Wang et al., 2012b) found that compared to that in the non-dust event the increased OC in the Mt. Hua dust samples mainly originated from Gobi plants.

$\mathrm{NO}_{3}^{-} / \mathrm{SO}_{4}^{2-}$ molar ratio was $1.22 \pm 0.48$ (range, $0.20-2.2$ ) in Xi' an and $0.60 \pm 0.36$ (range, 0.19-1.4) in Mt. Hua during the non-dust storm period. Compared to those in the nondust event the ratio of $\mathrm{NO}_{3}^{-} / \mathrm{SO}_{4}^{2-}$ during the DS II period decreased to $0.97 \pm 0.26$ (range, 0.67-1.2) in $\mathrm{Xi}^{\prime}$ an but was almost constant in Mt. Hua $(0.68 \pm 0.32,0.43-1.0)$ (Wang et al., 2011c). The major formation pathways of $\mathrm{NO}_{3}^{-}$and $\mathrm{SO}_{4}^{2-}$ in the atmosphere are the photo-oxidation of $\mathrm{NO}_{2}$ and $\mathrm{SO}_{2}$ with $\mathrm{OH}$ radical (Formenti et al., 2011; Jöckel et al., 2003; Seinfeld and Pandis, 1998), but the $\mathrm{NO}_{3}^{-}$forma- tion is about 10 times faster than that of $\mathrm{SO}_{4}^{2-}$ (Rodhe et al., 1981; Vrekoussis et al., 2004, 2007). Field observation showed that ground surface levels of $\mathrm{NO}_{2}$ and $\mathrm{SO}_{2}$ are similar in inland China. For example, annual means of $\mathrm{NO}_{2}$ and $\mathrm{SO}_{2}$ in Xi' an were 43 and $41 \mu \mathrm{g} \mathrm{m}^{-3}$ during 2006-2007 (Shen et al., 2008), $0.7 \pm 0.4$ and $0.6 \pm 0.4$ ppbv in Waliguan during 2007-2008 (Meng et al., 2010), and 2.7 \pm 1.6 and $2.2 \pm 0.7 \mathrm{ppbv}$ in Qinghai Lake in March-April, 2012 (unpublished data). Therefore, relative abundance of nitrate to sulfate higher in the urban air and lower in the mountain atmosphere can be explained firstly by the different formation rates and secondly by cloud processing at the summit of Mt. Hua, which favors sulfate formation. The different reaction rates also suggest that nitrate formation is only significant close to the source area but sulfate formation is continuous during the transport. Sulfate is non-volatile and the strongest acid, once formed in the dust it may prevent other weaker acids like $\mathrm{HNO}_{3}$ and $\mathrm{HCl}$ accumulate onto the dust (Sullivian et al., 2007). Therefore, compared to that in the nonevent the smaller $\mathrm{NO}_{3}^{-} / \mathrm{SO}_{4}^{2-}$ ratio in Xi' an during the DS II time further reveals a continuous formation of sulfate during the long-range transport of dust storm.

As shown in Fig. 7a, particles in the mountain troposphere during the non-dust event contained more sulfate compared to those in the urban air, but relative abundance of ammonium in the alpine $\mathrm{PM}_{10}$ samples was similar to that in the urban samples and nitrate was less than that in the urban samples, probably indicating a displacement of ammonium nitrate by ammonium bisulfate/sulfate in the mountain aerosols, which may occur during the transport of pollutants onto the mountaintop. During the DS II period the most significant differences in relative abundance between the ground surface and the mountain troposphere were found for $\mathrm{F}^{-}$and $\mathrm{EC}, 9$ times more abundant in the urban area than in the alpine region (Fig. 7b), because both pollutants in Guanzhong Basin are largely originated from lowland sources such as coal combustion and vehicle exhaust. Compared with those on the mountaintop, relative abundances of $\mathrm{NO}_{3}^{-}, \mathrm{Mg}^{2+}$ and $\mathrm{Ca}^{2+}$ in the DS II time at the urban site were much more abundant (Fig. 7b), which can be attributed to heterogeneous reactions of gaseous $\mathrm{HNO}_{3}, \mathrm{~N}_{2} \mathrm{O}_{5}$ and $\mathrm{NO}_{\mathrm{x}}$ with the crustal alkaline metals in the dust (Arimoto et al., 2004; Geng et al., 2009; Tobo et al., 2010; Triendl, 1998; Zamora et al., 2011). Xi' an and Mt. Hua are located in the same latitude with a distance about $80 \mathrm{~km}$, and transport velocity of dust storm is generally very fast. Furthermore, DS II event simultaneously occurred in Xi' an and Mt. Hua with a similar pattern of particle size distribution (see the details in Fig. 9s and $t$ and more discussion later). Therefore, it is plausible that the differences in relative abundances of components of $\mathrm{PM}_{10}$ between the urban and mountain sites can be ascribed to the reaction and/or adsorption of pollutants from local sources with dust during the DS II episode. Here we took the mountain particle composition as a reference and calculated the aerosol production from local source 

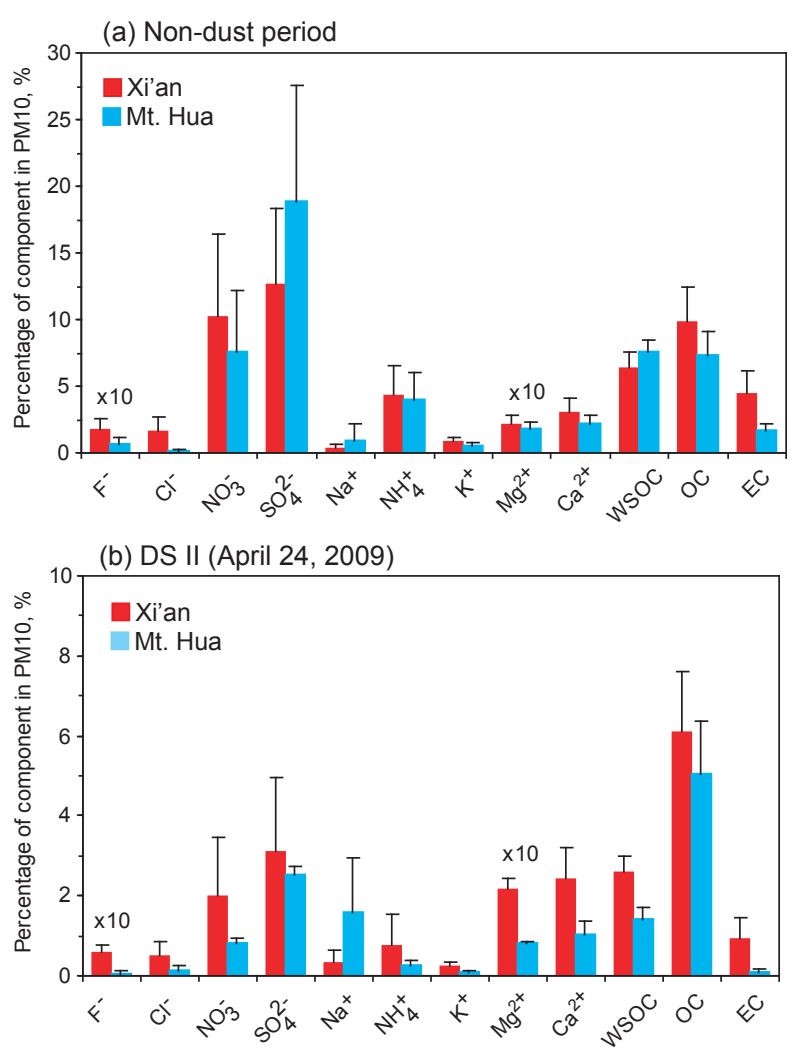

Fig. 7. Relative abundances of components of $\mathrm{PM}_{10}$ from Xi'an and Mt. Hua during (a) the non-dust storm and (b) the dust storm periods.

pollutants during the event using the following equation.

$A=C_{i}^{\mathrm{Xi}{ }^{\prime} \text { an }}-\left[\frac{C_{i}^{\mathrm{Mt} . \text { Hua }}}{\mathrm{PM}_{10}^{\mathrm{Mt.} \text { Hua }}}\right] \times \mathrm{PM}_{10}^{\mathrm{Xi}{ }^{\prime} \text { an }}$

where A is the pollutant $i$ formed from lowland sources $\left(\mu \mathrm{g} \mathrm{m}^{-3}\right), C_{i}^{\mathrm{Xi} \text { 'an }}$ and $C_{i}^{\mathrm{Mt} \text {. Hua }}$ are the concentrations of pollutant $i$ in the Xi' an and Mt. Hua dust samples.

We found that in the DS II event 6.1, 2.1, 2.6, 7.7, 7.5, 4.5 and $7.6 \mu \mathrm{g} \mathrm{m}^{-3}$ of $\mathrm{NO}_{3}^{-}, \mathrm{SO}_{4}^{2-}, \mathrm{NH}_{4}^{+}, \mathrm{Ca}^{2+}$, WSOC, EC and $\mathrm{OC}$ originated from local sources, accounting for $57 \%$, $12 \%, 66 \%, 59 \%, 48 \%, 87 \%$ and $22 \%$ of those in $\mathrm{PM}_{10}$, respectively (see Table 2). Compared with that $\left(2.1 \mu \mathrm{g} \mathrm{m}^{-3}\right.$, Table 2) of sulfate the nitrate formed from the local sources $\left(6.1 \mu \mathrm{g} \mathrm{m}^{-3}\right.$, Table 2) during the DS II was about three times higher, again confirming a faster heterogeneous formation of nitrate on the dust, which largely occurs on particles with diameter larger than $3.3 \mu \mathrm{m}$ (see more discussion below) and is consistent with the results reported previously (Phadnis and Carmichael, 2000). Interestingly, in the event abundance of WSOC formed from the local sources is almost entirely equal to that of OC $\left(7.5 \mu \mathrm{g} \mathrm{m}^{-3}\right.$ versus $7.6 \mu \mathrm{g} \mathrm{m}^{-3}$, Table 2$)$. This is reasonable because compared to Mt. Hua samples, an increase in $\mathrm{OC}$ of the $\mathrm{Xi}^{\prime}$ an samples resulted from heteroge- neous reactions of gaseous acids and amines with dust, which are water-soluble. Moreover, as shown in Table 2, same level increases of $\mathrm{K}^{+}(59 \%), \mathrm{Mg}^{2+}(61 \%)$, and $\mathrm{Ca}^{2+}(59 \%)$ were observed for the urban dust samples, which were caused by heterogeneous reactions of acidic gases with the urban dust particles. In comparison to those in the mountain samples the above similar levels of increases of WSOC, OC, $\mathrm{K}^{+}, \mathrm{Mg}^{2+}$ and $\mathrm{Ca}^{2+}$ again confirm that Xi' an and Mt. Hua were predominated by a same air mass in the DS II period.

To further recognize the sources of pollutants in Xi' an, major species in $\mathrm{PM}_{10}$ were analyzed using the statistic method of principal component analysis (PCA). As shown in Table 3, component 1 is associated with $\mathrm{F}^{-}, \mathrm{Cl}^{-}, \mathrm{K}^{+}$, WSOC, EC and OC, respectively, and represents fossil fuel and biomass combustion source, because $\mathrm{F}^{-}, \mathrm{K}^{+}$, WSOC and EC are largely derived from fossil fuel and biomass burning emission in China (Dan et al., 2004; Kline et al., 2004; Zhang et al., 2011). Component 2 represents dust emissions, because crustal species such as $\mathrm{Na}^{+}, \mathrm{Mg}^{2+}, \mathrm{Ca}^{2+}$, and WSIC showed strong correlations with this factor. The coefficient of WSON with component 2 is 0.60 , indicating soil/dust is an important source especially in the dust storm periods. Component 3 displays high loadings with $\mathrm{NO}_{3}^{-}, \mathrm{SO}_{4}^{2-}$ and $\mathrm{NH}_{4}^{+}$, and thus represents a source of secondary formation. These three components explain $44 \%, 29 \%$ and $8 \%$ of the total variance, respectively, and indicate fossil fuel/biomass combustion, soil/dust suspension and secondary formation as the major sources of $\mathrm{PM}_{10}$ in the city.

\subsection{Size distribution}

Almost all physicochemical and optical properties of aerosol are size-dependent (Hinds, 1999). The size of ambient aerosol varies during transport due to various atmospheric processes such as coagulation, evaporation, and adsorption/absorption (Herner et al., 2006). Detailed size distributions of particle mass (PM), inorganic ions and water-soluble organic (WSOC) and inorganic (WSIC) carbon during the nonevent and the event (DS II) are illustrated in Fig. 8 and Fig. 9, respectively. Their relative abundances in each size range are summarized in Table 4. Details in size distributions of major species during the same period in the troposphere over Mt. Hua have been reported elsewhere (Wang et al., 2011c) and are cited here for a comparison.

\subsubsection{Difference in size distribution of aerosols from Xi'an and Mt. Hua during the non-dust storm period}

Particle mass (PM) showed a bimodal pattern in Xi' an during the nonevent with coarse particles $(>2.1 \mu \mathrm{m})$ as the major fraction (Fig. 8a), accounting for about $60 \%$ of the total particle mass (Table 4). Similar distribution was also found at the summit of Mt. Hua (Fig. 8b), suggesting an importance of coarse particles in the atmosphere over the whole 
Table 2. Concentrations of species derived from local sources and their relative abundance to the total in $\mathrm{PM}_{10}$ samples of Xi' an during the dust storm event (DS II, 24 April 2009).

\begin{tabular}{|c|c|c|c|c|c|c|c|c|c|c|c|}
\hline & $\mathrm{F}^{-}$ & $\mathrm{Cl}^{-}$ & $\mathrm{NO}_{3}^{-}$ & $\mathrm{SO}_{4}^{2-}$ & $\mathrm{NH}_{4}^{+}$ & $\mathrm{K}^{+}$ & $\mathrm{Mg}^{2+}$ & $\mathrm{Ca}^{2+}$ & WSOC & $\mathrm{EC}$ & $\mathrm{OC}$ \\
\hline Concentrations of species from local sources, $\mu \mathrm{g} \mathrm{m}^{-3}$ & 0.3 & 2.0 & 6.1 & 2.1 & 2.6 & 0.8 & 0.8 & 7.7 & 7.4 & 4.5 & 7.6 \\
\hline Relative abundance to the total in $\mathrm{PM}_{10}, \%$ & 87 & 67 & 57 & 12 & 66 & 59 & 61 & 59 & 48 & 87 & 22 \\
\hline
\end{tabular}

(I) Non-dust storm period (March 25-April 25,2009)

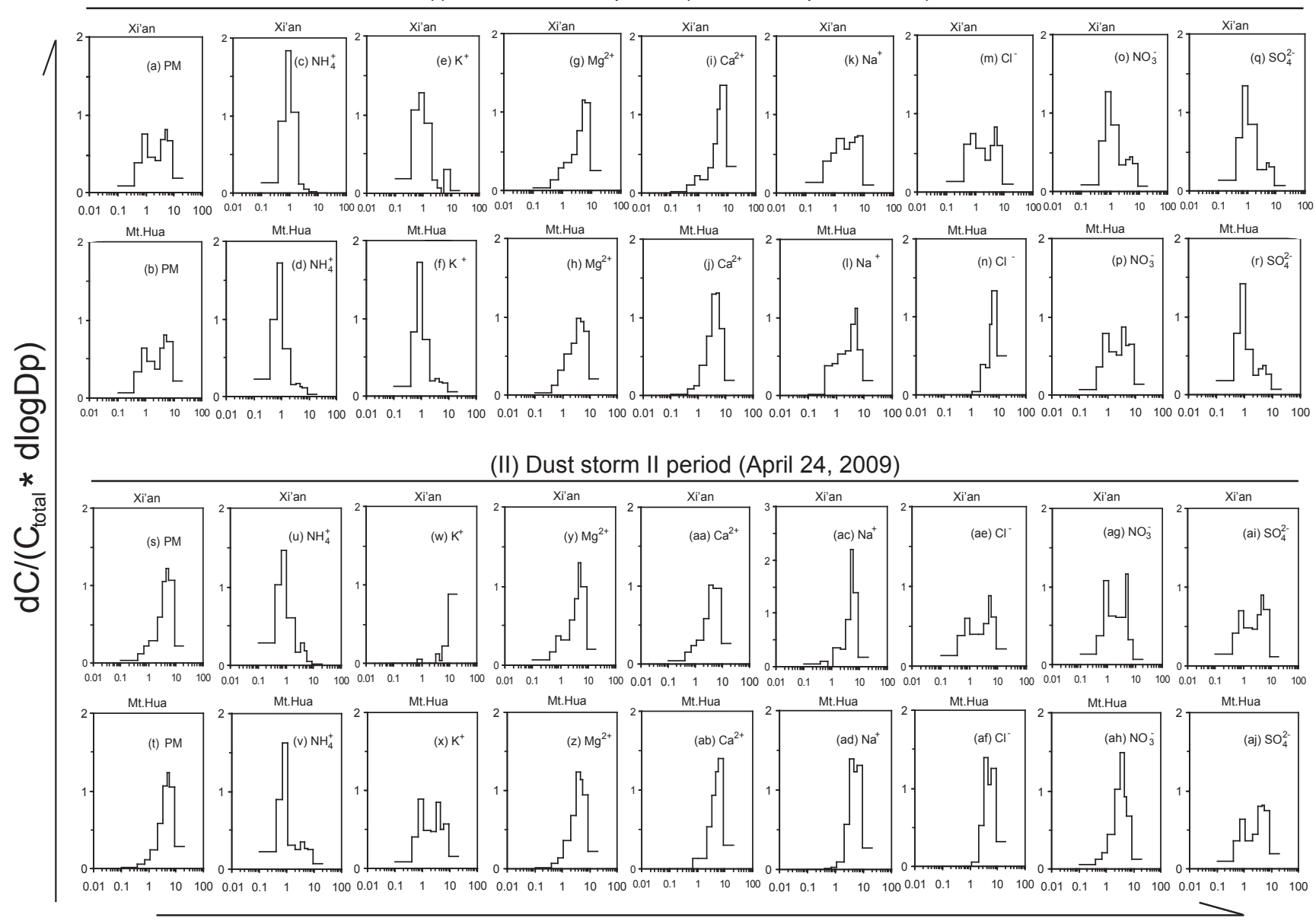

Particle size, $\mathrm{Dp}(\mu \mathrm{m})$

Fig. 8. Differences in size distributions of particle mass (PM) and inorganic ions in the atmospheres of Xi' an and Mt. Hua during (I) the non-dust storm and (II) the dust storm periods.

Guanzhong Basin in spring. Ammonium presented a unimodal pattern in the urban air with the highest peak at the size of $0.7-1.1 \mu \mathrm{m}$ (Fig. 8c). Potassium ion showed a bimodal pattern with a major peak in the fine mode $(<2.1 \mu \mathrm{m})$ and small peak in the coarse mode $(>2.1 \mu \mathrm{m})$ (Fig. 8e). Particulate ammonium is formed by a homogeneous reaction of ammonia with acidic gasses such $\mathrm{HNO}_{3}$ and $\mathrm{HCl}$ and a subsequent partition into solid phase and/or a heterogeneous reaction of ammonia with aqueous sulfuric acid. Therefore, a fine mode of ammonium was found at both sites (Fig. 8c, d). The small fraction of ammonium in the coarse fraction is mostly derived from suspended soil containing fertilizer. Generally, fine mode of $\mathrm{K}^{+}$is mostly derived from biomass burning while the coarse mode $\mathrm{K}^{+}$can be attributed to suspended soil (Fig. 8e) (Zhang et al., 2011). Such a soil-derived $\mathrm{K}^{+}$ is less significant at the mountaintop, thus only a unimodal pattern was observed in the elevated troposphere (Fig. 8f). $\mathrm{Mg}^{2+}$ and $\mathrm{Ca}^{2+}$ have dominant crustal origins, and both showed a coarse mode between the boundary layer and the elevated troposphere (Fig. $8 \mathrm{q}-\mathrm{j}$ ). $\mathrm{Na}^{+}$is an important component in soil, thus it occurred abundantly in the coarse fraction during the non-dust event at both sites (Fig. 8k, 1). The 
Table 3. Principal component analysis for $\mathrm{PM}_{10}$ of Xi' an during the whole sampling period $(N=64)$.

\begin{tabular}{lrrr}
\hline & \multicolumn{3}{c}{ Component } \\
\hline & 1 & 2 & 3 \\
$\mathrm{PM}_{10}$ & 0.27 & $\mathbf{0 . 9 2}$ & 0.10 \\
$\mathrm{~F}^{-}$ & $\mathbf{0 . 8 0}$ & 0.28 & 0.14 \\
$\mathrm{Cl}^{-}$ & $\mathbf{0 . 8 8}$ & 0.12 & 0.16 \\
$\mathrm{NO}_{3}^{-}$ & 0.25 & -0.04 & $\mathbf{0 . 9 2}$ \\
$\mathrm{SO}_{4}^{2-}$ & 0.19 & 0.08 & $\mathbf{0 . 9 3}$ \\
$\mathrm{Na}^{+}$ & 0.23 & $\mathbf{0 . 6 5}$ & 0.04 \\
$\mathrm{NH}_{4}^{+}$ & 0.22 & -0.17 & $\mathbf{0 . 9 5}$ \\
$\mathrm{K}^{+}$ & $\mathbf{0 . 7 2}$ & 0.11 & $\mathbf{0 . 6 1}$ \\
$\mathrm{Mg}^{2+}$ & 0.34 & $\mathbf{0 . 8 9}$ & 0.11 \\
$\mathrm{Ca}^{2+}$ & 0.34 & $\mathbf{0 . 7 8}$ & -0.12 \\
$\mathrm{WSOC}^{2+}$ & $\mathbf{0 . 6 2}$ & 0.22 & 0.40 \\
WSIC & -0.09 & $\mathbf{0 . 6 8}$ & $-\mathbf{0 . 6 2}$ \\
EC & $\mathbf{0 . 9 0}$ & 0.07 & 0.33 \\
OC & $\mathbf{0 . 8 3}$ & 0.47 & 0.04 \\
WSON & -0.21 & $\mathbf{0 . 6 0}$ & -0.38 \\
\%Variance & $44 \%$ & $29 \%$ & $8 \%$ \\
\hline * Absolute values more than 0.5 are highlighted in bold
\end{tabular}

fine fraction of $\mathrm{Na}^{+}$can be explained by a biomass burning contribution, because biomass smoke contains a significant amount of $\mathrm{Na}_{2} \mathrm{SO}_{4}$ (Andreae et al., 1998). $\mathrm{Cl}^{-}$showed an accumulation mode and a coarse mode in the urban area (Fig. 8m) but only exhibited a coarse mode in the mountain atmosphere (Fig. 8n). $\mathrm{KCl}$ is one of major species of airborne particulate $\mathrm{Cl}^{-}$, which is produced in the biomass combustion process and emitted into the air as fine particles. During the ageing process of biomass burning plume $\mathrm{KCl}$ can react with gaseous $\mathrm{HNO}_{3}$ and $\mathrm{H}_{2} \mathrm{SO} 4$ and release $\mathrm{HCl}$ into the air (Ikegami et al., 2001; Li et al., 2003; Posfai et al., 2003). The gaseous $\mathrm{HCl}$ further transforms into aerosol phase by reaction with coarse particles (Hand et al., 2005; Tobo et al., 2010). Therefore, a bimodal pattern of $\mathrm{Cl}^{-}$was obtained in the urban region (Fig. 8m). That the fine mode peak of $\mathrm{Cl}^{-}$was not evident at the mountain site indicates that the biomass burning derived aerosols was more aged when they arrived at the mountaintop (Fig. 8n). Because both are secondarily produced in the atmosphere, nitrate and sulfate are largely distributed in fine particles (Fig. 8o-r). The coarse mode of nitrate and sulfate can be attributable to uptake of gaseous $\mathrm{HNO}_{3}$ and $\mathrm{H}_{2} \mathrm{SO}_{4}$ onto coarse particles. In addition, sulfate in the coarse mode also has a soil primary emission source, since loess and desert dust also contain a certain amount of sulfate (Sun et al., 2010). Ammonium nitrate is the major form of particulate $\mathrm{NO}_{3}^{-}$, which is volatile and easily converts to gaseous $\mathrm{NH}_{3}$ and $\mathrm{HNO}_{3}$. As discussed above the reaction of $\mathrm{SO}_{2}$ with $\mathrm{OH}$ radical to produce $\mathrm{H}_{2} \mathrm{SO}_{4}$ is slower compared to that of $\mathrm{NO}_{\mathrm{x}}$ with $\mathrm{OH}$ to form $\mathrm{HNO}_{3}$, thus it is expected that sulfate may be continuously formed during the transport of the precursors from the boundary layer to the free troposphere. The newly formed sulfate can displace the pre-existing nitrate into the air, because sulfuric acid is the strongest and nonvolatile (Sullivian et al., 2007). Due to the above reasons nitrate continuously redistributes from fine particles onto coarse particle during long-range transport while sulfate remains in fine particles, resulting in the size distribution of nitrate changing into a bimodal pattern with two equivalent peaks in the fine and coarse fractions in the mountain air but no significant change for sulfate (Fig. 8p, r).

\subsubsection{Difference in size distribution of aerosols from Xi'an and Mt. Hua during dust storm on 24 April 2009 (DS II)}

When dust was present all species in the urban air shifted toward larger sizes (Fig. 8s-ai), similar to those on the mountaintop (Fig. 8-aj). Compared to particle size distribution sampled in the nonevent, a greater portion of particles during the dust event was present in the coarse mode (Fig. 8s, t). As in the nonevent, ammonium was enriched in the fine mode, but a minor peak occurred in the coarse fraction (Fig. 8u, v), which can be attributed to fertilizer and biota in the dust. Ammonium in the size of $1.1-2.1 \mu \mathrm{m}$ in Xi' an (Fig. $8 \mathrm{u}$ ) and Mt. Hua (Fig. 8v) during the dust episode became less abundant compared to that in the nonevent at both sites (Fig. 8c, d), which is in part resulted from a less significant fine particle coagulation due to reduced residence time in the event compared with that in the nonevent (Wang et al., 2012b). Because $\mathrm{K}^{+}, \mathrm{Mg}^{2+}, \mathrm{Ca}^{2+}$ and $\mathrm{Na}^{+}$are originated from Gobi desert dust, these four ions dominated in the coarse mode in $\mathrm{Xi}$ 'an during the event (Fig. $8 \mathrm{w}-\mathrm{ac}$ ), which is similar to those in the mountain atmosphere except $\mathrm{K}^{+}$(Fig. 8x-ad) and indicates a predominance of dust in the whole Guanzhong Basin from the boundary layer to the free troposphere during the DS II period. The fine mode of $\mathrm{K}^{+}$at Mt. Hua in the event is probably resulted from local biomass burning in the mountain area (Fig. 8x). As seen in Fig. 8ae, $\mathrm{Cl}^{-}$presented a bimodal pattern with an increased coarse fraction in the event in Xi' an compared to that (Fig. 8m) in the nonevent. The fine mode $\mathrm{Cl}^{-}$in the urban area during the event is mostly due to biomass burning emissions, whereas the coarse modes of $\mathrm{Cl}^{-}$in the urban and the alpine atmospheres during the event are probably derived from the dried salt lakes in north China and Gobi regions. Size distribution pattern of nitrate in the urban air changed from a dominance in the fine mode during the nonevent into a bimodal pattern with two equivalent peaks in the fine and coarse ranges during the DS II period (Fig. 8o, ag), indicating a significant shift of $\mathrm{NO}_{3}^{-}$from fine particles into large dust during the episode. Such a redistribution was further pronounced in the mountain troposphere, resulting in a dominance in the coarse mode at Mt. Hua with no peak in the fine mode (Fig. 8ah). However, size distributions of sulfate at both sites were similar during the event with an increased peak in the coarse mode compared to those 
Table 4. Concentration percentages (\%) of particle mass (PM), inorganic ions, water-soluble organic carbon (WSOC), water-soluble inorganic carbon (WSIC) and water-soluble organic nitrogen (WSON) in the size-resolved aerosols from Xi' an and Mt. Hua during the spring of 2009.

\begin{tabular}{|c|c|c|c|c|c|c|c|c|c|c|c|c|c|}
\hline Size range, $\mu \mathrm{m}$ & $\mathrm{PM}$ & $\mathrm{F}^{-}$ & $\mathrm{Cl}^{-}$ & $\mathrm{NO}_{3}^{-}$ & $\mathrm{SO}_{4}^{2-}$ & $\mathrm{Na}^{+}$ & $\mathrm{NH}_{4}^{+}$ & $\mathrm{K}^{+}$ & $\mathrm{Mg}^{2+}$ & $\mathrm{Ca}^{2+}$ & WSOC & WSIC & WSON \\
\hline \multicolumn{14}{|c|}{$\begin{array}{l}\text { I. Non-dust storm period } \\
\text { (a) Xi' an }(N=5)\end{array}$} \\
\hline$>9.0$ & $23 \pm 4.9$ & $24 \pm 2.8$ & $10 \pm .4$ & $6.9 \pm 2.5$ & $7.5 \pm 1.4$ & $11 \pm 1.9$ & $0.5 \pm 0.1$ & $2.8 \pm 1.5$ & $25 \pm 4.3$ & $35 \pm 5.5$ & $4.4 \pm 3.3$ & $37 \pm 4.1$ & $0.7 \pm 1.2$ \\
\hline $5.8-9.0$ & $14 \pm 1.2$ & $22 \pm 4.7$ & $11 \pm 2.9$ & $6.8 \pm 1.3$ & $6.2 \pm 1.5$ & $14 \pm 6.1$ & $0.3 \pm 0.2$ & $6.1 \pm 6.8$ & $22 \pm 5.3$ & $27 \pm 4.5$ & $4.5 \pm 4.8$ & $25 \pm 7.5$ & $1.3 \pm 1.1$ \\
\hline $4.7-5.8$ & $7.5 \pm 2.3$ & $15 \pm 1.6$ & $7.7 \pm 2.9$ & $4.0 \pm 0.8$ & $3.3 \pm 0.4$ & $6.4 \pm 2.5$ & $0.2 \pm 0.1$ & $0.0 \pm 0.0$ & $11 \pm 1.4$ & $9.9 \pm 2.0$ & $5.4 \pm 4.5$ & $16 \pm 4.4$ & $1.0 \pm 0.6$ \\
\hline $3.3-4.7$ & $9.9 \pm 2.8$ & $21 \pm 1.8$ & $9.4 \pm 4.2$ & $6.3 \pm 2.1$ & $4.2 \pm 0.4$ & $9.5 \pm 2.9$ & $0.8 \pm 0.3$ & $1.0 \pm 0.8$ & $12 \pm 0.9$ & $9.7 \pm 1.0$ & $3.3 \pm 1.3$ & $12 \pm 0.7$ & $2.6 \pm 0.4$ \\
\hline $2.1-3.3$ & $7.3 \pm 3.2$ & $14 \pm 1.9$ & $8.1 \pm 1.5$ & $6.5 \pm 1.0$ & $5.2 \pm 0.4$ & $11 \pm 1.8$ & $2.2 \pm 0.3$ & $3.5 \pm 1.8$ & $9.0 \pm 0.8$ & $6.3 \pm 0.7$ & $4.3 \pm 1.6$ & $2.9 \pm 0.6$ & $3.2 \pm 0.6$ \\
\hline $1.1-2.1$ & $13 \pm 1.2$ & $1.8 \pm 2.9$ & $16 \pm 3.4$ & $24 \pm 3.2$ & $24 \pm 3.1$ & $19 \pm 3.4$ & $29 \pm 4.3$ & $26 \pm 6.1$ & $10 \pm 0.5$ & $4.7 \pm 0.5$ & $17 \pm 3.6$ & $1.8 \pm 0.7$ & $20 \pm 4.4$ \\
\hline $0.7-1.1$ & $13 \pm 2.9$ & $0.0 \pm 0.0$ & $15 \pm 3.3$ & $25 \pm 3.5$ & $26 \pm 1.9$ & $10 \pm 5.7$ & $36 \pm 1.9$ & $27 \pm 7.9$ & $5.5 \pm 0.7$ & $4.1 \pm 1.1$ & $26 \pm 11$ & $1.3 \pm 0.8$ & $40 \pm 8.9$ \\
\hline $0.4-0.7$ & $8.1 \pm 1.6$ & $0.0 \pm 0.0$ & $15 \pm 7.1$ & $16 \pm 1.7$ & $16 \pm 1.4$ & $10 \pm 1.2$ & $23 \pm 1.8$ & $24 \pm 10$ & $3.4 \pm 0.3$ & $2.2 \pm 1.0$ & $28 \pm 15$ & $2.0 \pm 0.6$ & $23 \pm 1.5$ \\
\hline$<0.4$ & $4.5 \pm 0.4$ & $2.1 \pm 3.3$ & $8.2 \pm 3.8$ & $5.3 \pm 1.0$ & $7.8 \pm 1.6$ & $8.1 \pm 1.2$ & $8.1 \pm 2.2$ & $9.9 \pm 7.1$ & $2.4 \pm 0.4$ & $1.2 \pm 0.9$ & $7.1 \pm 2.5$ & $3.2 \pm 1.5$ & $8.1 \pm 3.0$ \\
\hline Total & 100 & 100 & 100 & 100 & 100 & 100 & 100 & 100 & 100 & 100 & 100 & 100 & 100 \\
\hline \multicolumn{14}{|c|}{ (b) Mt. Hua $(N=3)$} \\
\hline$>9.0$ & $19 \pm 2.4$ & $40 \pm 25$ & $52 \pm 14$ & $15 \pm 3.4$ & $7.3 \pm 6.0$ & $20 \pm 3.4$ & $3.1 \pm 3.2$ & $4.7 \pm 3.6$ & $23 \pm 11$ & $27 \pm 12$ & $\mathrm{NA}^{\mathrm{a}}$ & NA & NA \\
\hline $5.8-9.0$ & $13 \pm 1.1$ & $25 \pm 6.5$ & $25 \pm 16$ & $12 \pm 4.1$ & $4.5 \pm 1.9$ & $11 \pm 6.1$ & $1.9 \pm 1.4$ & $2.5 \pm 0.7$ & $15 \pm 2.0$ & $18 \pm 2.8$ & NA & NA & NA \\
\hline $4.7-5.8$ & $7.3 \pm 0.6$ & $5.6 \pm 4.9$ & $8.2 \pm 13$ & $5.8 \pm 1.9$ & $3.1 \pm 1.1$ & $10 \pm 6.0$ & $1.0 \pm 0.5$ & $1.5 \pm 1.8$ & $7.6 \pm 0.5$ & $8.8 \pm 1.6$ & NA & NA & NA \\
\hline $3.3-4.7$ & $10 \pm 1.0$ & $19 \pm 6.5$ & $5.4 \pm 9.3$ & $13 \pm 3.9$ & $4.3 \pm 1.3$ & $14 \pm 2.2$ & $2.1 \pm 1.1$ & $2.6 \pm 0.8$ & $14 \pm 1.3$ & $15 \pm 2.5$ & NA & NA & NA \\
\hline $2.1-3.3$ & $8.1 \pm 0.5$ & $6.3 \pm 6.1$ & $7.6 \pm 13$ & $10 \pm 2.1$ & $4.7 \pm 1.0$ & $11 \pm 3.6$ & $2.8 \pm 1.7$ & $3.6 \pm 1.4$ & $13 \pm 2.6$ & $11 \pm 3.2$ & $\mathrm{NA}$ & NA & NA \\
\hline $1.1-2.1$ & $13 \pm 1.6$ & $3.2 \pm 5.5$ & $1.3 \pm 2.3$ & $15 \pm 3.3$ & $18 \pm 4.5$ & $15 \pm 2.0$ & $20 \pm 4.9$ & $23 \pm 6.2$ & $16 \pm 3.9$ & $8.4 \pm 1.7$ & $\mathrm{NA}$ & NA & NA \\
\hline $0.7-1.1$ & $15 \pm 1.4$ & $0.1 \pm 0.1$ & $0.0 \pm 0.0$ & $16 \pm 5.3$ & $30 \pm 7.1$ & $8.3 \pm 2.3$ & $35 \pm 4.7$ & $35 \pm 3.2$ & $6.6 \pm 1.6$ & $4.5 \pm 0.4$ & NA & NA & NA \\
\hline $0.4-0.7$ & $9.4 \pm 1.5$ & $0.3 \pm 0.5$ & $0.0 \pm 0.0$ & $8.9 \pm 2.8$ & $18 \pm 4.8$ & $9.2 \pm 4.2$ & $22 \pm 6.0$ & $20 \pm 6.6$ & $3.0 \pm 1.2$ & $3.6 \pm 0.7$ & NA & NA & NA \\
\hline$<0.4$ & $5.5 \pm 1.9$ & $0.0 \pm 0.0$ & $0.0 \pm 0.0$ & $3.8 \pm 2.4$ & $9.1 \pm 4.2$ & $0.8 \pm 1.4$ & $11 \pm 5.4$ & $7.7 \pm 5.4$ & $1.7 \pm 0.3$ & $2.6 \pm 0.7$ & $\mathrm{NA}$ & NA & NA \\
\hline Total & 100 & 100 & 100 & 100 & 100 & 100 & 100 & 100 & 100 & 100 & NA & NA & NA \\
\hline \multicolumn{14}{|c|}{$\begin{array}{l}\text { II. Dust storm period (DS II, } 24 \text { April 2009) } \\
\text { (a) Xi'an }(N=1)\end{array}$} \\
\hline$>9.0$ & 23 & $\mathrm{ND}^{\mathrm{b}}$ & 23 & 7.0 & 13 & 18 & 1.4 & 93 & 21 & 31 & 31 & 16 & 0.3 \\
\hline $5.8-9.0$ & 21 & ND & 12 & 6.2 & 14 & 27 & 0.9 & 4.2 & 19 & 27 & 16 & 20 & 17 \\
\hline $4.7-5.8$ & 11 & ND & 8.1 & 11 & 8.2 & 20 & 1.7 & 0.2 & 12 & 11 & 11 & 11 & 0.3 \\
\hline $3.3-4.7$ & 16 & ND & 8.1 & 9.3 & 9.9 & 14 & 4.4 & 1.9 & 13 & 14 & 13 & 16 & 13 \\
\hline $2.1-3.3$ & 12 & ND & 7.7 & 12 & 9.1 & 6.3 & 3.2 & 0.0 & 11 & 11 & 13 & 9.6 & 12 \\
\hline $1.1-2.1$ & 8.2 & ND & 11 & 17 & 14 & 9.8 & 17 & 0.0 & 8.9 & 3.8 & 1.4 & 7.5 & 6.7 \\
\hline $0.7-1.1$ & 4.3 & ND & 12 & 21 & 14 & 0.0 & 29 & 1.1 & 7.1 & 2.6 & 11 & 5.4 & 0.3 \\
\hline $0.4-0.7$ & 2.7 & ND & 9.4 & 9.0 & 10 & 2.5 & 25 & 0.0 & 4.0 & 0.0 & 2.3 & 7.8 & 33 \\
\hline$<0.4$ & 2.1 & ND & 8.5 & 7.7 & 9.1 & 3.4 & 18 & 0.0 & 3.6 & 0.0 & 1.6 & 6.6 & 17 \\
\hline Total & 100 & ND & 100 & 100 & 100 & 100 & 100 & 100 & 100 & 100 & 100 & 100 & 100 \\
\hline \multicolumn{14}{|c|}{ (b) Mt. Hua $(N=1)$} \\
\hline$>9.0$ & 30 & ND & 33 & 13 & 20 & 28 & 6.9 & 16 & 23 & 21 & NA & NA & NA \\
\hline $5.8-9.0$ & 20 & ND & 24 & 13 & 14 & 25 & 4.9 & 11 & 18 & 16 & NA & NA & NA \\
\hline $4.7-5.8$ & 11 & ND & 9.6 & 8.4 & 7.5 & 11 & 2.5 & 4.6 & 10 & 12 & $\mathrm{NA}$ & NA & NA \\
\hline $3.3-4.7$ & 16 & ND & 21 & 23 & 12 & 21 & 5.3 & 13 & 19 & 20 & NA & NA & NA \\
\hline $2.1-3.3$ & 11 & ND & 10 & 20 & 8.7 & 11 & 5.0 & 9.4 & 13 & 15 & NA & NA & NA \\
\hline $1.1-2.1$ & 6.8 & ND & 1.5 & 12 & 10 & 2.6 & 8.8 & 14 & 10 & 11 & NA & NA & NA \\
\hline $0.7-1.1$ & 2.1 & ND & 0.0 & 4.1 & 12 & 0.4 & 32 & 17 & 2.7 & 2.4 & $\mathrm{NA}$ & NA & NA \\
\hline $0.4-0.7$ & 1.4 & ND & 0.0 & 2.9 & 8.7 & 0.2 & 22 & 10 & 1.7 & 2.0 & $\mathrm{NA}$ & NA & NA \\
\hline$<0.4$ & 1.1 & ND & 0.0 & 3.2 & 5.7 & 0.0 & 13 & 5.4 & 0.8 & 1.1 & NA & NA & NA \\
\hline Total & 100 & ND & 100 & 100 & 100 & 100 & 100 & 100 & 100 & 100 & $\mathrm{NA}$ & NA & NA \\
\hline
\end{tabular}

a NA: not available due to limited materials on the sample filter; ${ }^{\mathrm{b}}$ ND: not determined.

in the nonevent (Fig. 8ai, aj). The coarse mode of sulfate can be explained by an increasing input of dust, because dust particles from deserts in Northwest China and Gobi region contain a certain amount of sulfate (Sun et al., 2010). In addition, heterogeneous reaction of $\mathrm{SO}_{2}$ with dust and/or uptake of $\mathrm{H}_{2} \mathrm{SO}_{4}$ onto dust may also be responsible for the shift towards the coarse mode (Huang et al., 2012; Li et al., 2011; Sun et al., 2010; Takahashi et al., 2010; Zhang et al., 2003).

\subsubsection{Size distribution of WSOC, WSIC and WSON in Xi'an}

Due to limited materials on the filters size distributions of WSOC, WSIC and WSON were not determined for Mt. Hua samples. Instead, the size distributions were only measured for the urban samples. WSOC in the urban atmospheric presented a predominance in the fine mode with a small peak in the coarse mode during the nonevent, in contrast to a unimodal pattern of WSIC, which is dominant in the coarse mode (Fig. 9a-d). Several studies have reported that particulate WSOC in an urban environment is largely formed 


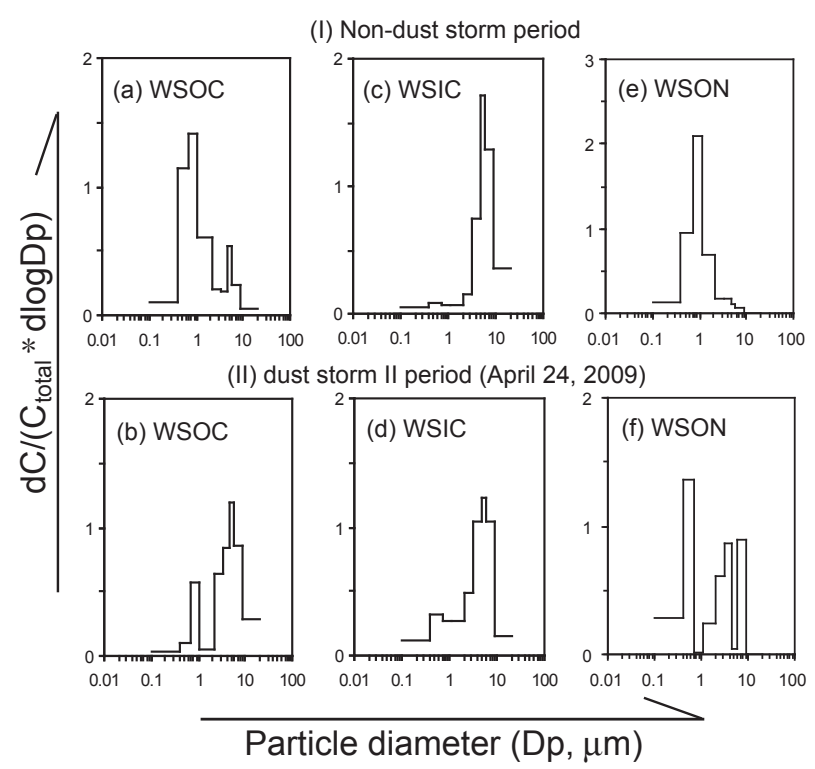

Fig. 9. Size distribution of water-soluble organic carbon (WSOC), inorganic carbon (WSIC) and organic nitrogen (WSON) in Xi' an during (I) the non-dust storm and (II) the dust storm periods.

from photochemical oxidation of organic gases (Agarwal et al., 2010; Ram and Sarin, 2010; Salma et al., 2007; Wang et al., 2012a; Yu et al., 2004, 2005). Moreover, biomass burning is also an important source of WSOC. Thus a major peak in the fine mode was found in Xi' an during the non-dust storm period (Fig. 9a). The small peak of coarse mode of WSOC can be explained by a nature source such as pollen and soil (Fig. 9a), because water-soluble organic compounds like glucose (Graham et al., 2002; Wang et al., 2006b, 2009, 2011a, b) and humic acid (Brooks et al., 2004; Dinar et al., 2006; Havers et al., 1998) are enriched in these sources, in addition to deposition of anthropogenic pollutants onto dust. During the dust storm period WSOC still displayed a bimodal pattern, but the fine mode significantly decreased while the coarse mode sharply increased as a dominant peak. Our previous study (Wang et al., 2012b) found that during the DS II period secondary organic aerosols in the Mt. Hua air were mostly formed from the local sources rather than being transported from the upwind region, and are of a size within the fine mode. However, during the event primary organic aerosols such as water-soluble organic compounds, such as glucose and trehalose and water-insoluble organic compounds like high molecular weight (HMW) $n$ alkanes, fatty acids and fatty alcohols, were mostly derived from biota, e.g. pollen, spore, invertebrate animals and plants in Gobi desert (Wang et al., 2012b). Those Gobi dust derived organic aerosols are of larger sizes and dominated in the downwind atmosphere in the event, resulting in a sharp increase in OC in the atmospheres of Mt. Hua and Mt. Tai in comparison to those in the nonevent (Wang et al., 2011c;
Wang et al., 2012b). Therefore, a large peak in the coarse fraction and a small peak in the fine fraction were observed for WSOC in Xi' an in the DS II event (Fig. 9b).

As the major species of WSIC in the atmosphere, both carbonate $\left(\mathrm{CO}_{3}^{2-}\right)$ and bicarbonate $\left(\mathrm{HCO}_{3}^{-}\right)$ions are derived from soil and thus show a coarse mode in the nonevent (Fig. 9c). In the DS II time WSIC exhibited a bimodal pattern with a small peak in the fine mode and a large peak in the coarse mode (Fig. 9d). Such an increase of WSIC in the fine mode can be ascribed to an aqueous phase reaction of $\mathrm{HNO}_{3} / \mathrm{H}_{2} \mathrm{SO}_{4}$ with fine calcite particles (Dunlea et al., 2009; Leaitch et al., 2009; McNaughton et al., 2009; Sullivan et al., $2007,2009 \mathrm{~b}$ ), which was $3.4 \mu \mathrm{g} \mathrm{m}^{-3}$ in the DS II event and 10 times higher than that $\left(0.3 \pm 0.1 \mu \mathrm{g} \mathrm{m}^{-3}\right)$ in the nonevent.

Water-soluble organic nitrogen (WSON) are a class of complex nitrogen-containing compounds such as urea, amines, amino acids, peptides and proteins, which are derived from urban pollution, biomass burning, dust and sea spray (Altieri et al., 2012; Cape et al., 2011; Chen and Chen, 2010; Mace et al., 2003b; Violaki and Mihalopoulos, 2011; Zhang and Anastasio, 2003). WSON concentrated in fine particles as a unimodal pattern during the nonevent with $90 \%$ of the total mass enriched in fine mode $(<2.1 \mu \mathrm{m})$ (Fig. 9e and Table 4), which is similar to $\mathrm{NH}_{4}^{+}$(Fig. 8c). When dust was present WSON exhibited a bimodal pattern with one peak in the fine mode and two peaks in the coarse mode (Fig. 9f). The coarse mode fraction accounts for $43 \%$ of the total WSON, much more than that in the nonevent time (Table 4). Zamora et al. (2011) observed that compared to that in Barbados, WSON in Miami increased by a factor of two when Sahara dust was present, although the actual dust concentrations at both cities were almost the same. Similar results were also observed in Mediterranean (Mace et al., 2003c). The sharply enhanced WSON in Xi' an and the above documented phenomena can be explained by an increased deposition of volatile alkylamines onto dust particles via adsorption and/or heterogeneous reaction (Mace et al., 2003a; Qiu et al., 2011). In addition, the coarse mode of WSON may also be directly originated from biological organisms in Gobi dust, which contains a certain amount of WSON species (Mace et al., 2003a).

\subsection{Difference in aerosol acidity between Xi'an and Mt. Hua}

Figure 10 plots the equivalent ratios of total measured ions in particle with different sizes in Xi' an. For particles with diameter less than $2.1 \mu \mathrm{m}$ (Fig. 10a), the ratios of total cations to total anions were less than unity in both nonevent and event periods, suggesting an acidic nature of fine particles, but the slope of the regression line was smaller in the dust storm period (0.37) than in the non-dust period $(0.80)$, indicating that fine particles in the event were more acidic. On Mt. Hua the slope of the regression line was 0.6 in the nonevent and increased to 0.9 on 24 April (Fig. 10b and the 


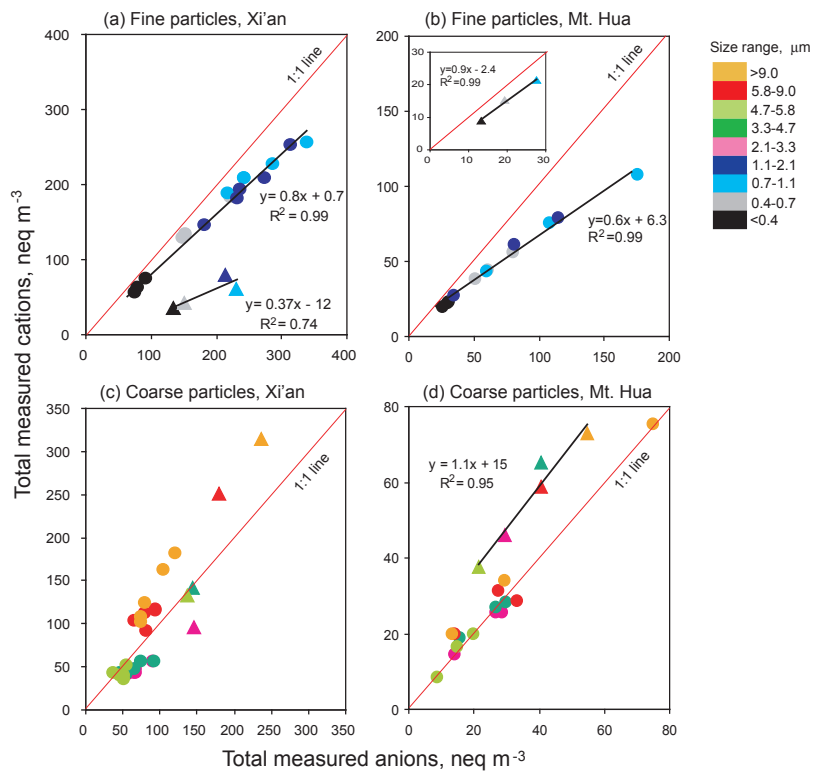

Fig. 10. Acidity of size-segregated samples in Xi' an and Mt. Hua during the non-dust storm (circle symbols) and dust storm (24 April 2009 , triangle symbols) periods.

inserted figure), which means fine particles in the free troposphere became less acidic when dust was present. To our best knowledge, such an opposite trend of aerosol acidity between the boundary layer and free troposphere is found for the first time. We believed it is mostly caused by the difference in $\mathrm{NO}_{3}^{-}$production. As mentioned above, $\mathrm{NO}_{3}^{-}$is largely formed by oxidation of $\mathrm{NO}_{2}$ with $\mathrm{OH}$ radical, which is much faster than the oxidation of $\mathrm{SO}_{2}$ with $\mathrm{OH}$ to form $\mathrm{SO}_{4}^{2-}$ (Jöckel et al., 2003; Rodhe et al., 1981; Seinfeld and Pandis, 1998). Atmospheric $\mathrm{SO}_{4}^{2-}$ can also be produced via heterogeneous reaction of $\mathrm{SO}_{2}$ with $\mathrm{H}_{2} \mathrm{O}_{2}$ in cloud/aqueous phase, but the reaction rate $\left(k=6 \times 10^{-16} \mathrm{~cm}^{3}\right.$ molecules $\left.{ }^{-1} \mathrm{~s}^{-1}\right)$ is also much lower than the $\mathrm{NO}_{3}^{-}$production rate $(k=8 \times$ $10^{-12} \mathrm{~cm}^{3}$ molecules ${ }^{-1} \mathrm{~s}^{-1}$ ) (Rodhe et al., 1981). Laboratory study (Sullivan et al., 2009b) showed that calcite, which abundantly exists in East Asian dust, can rapidly convert to $\mathrm{Ca}\left(\mathrm{NO}_{3}\right)_{2}$ less than 3 min under 1 ppbv $\mathrm{HNO}_{3} \cdot \mathrm{Ca}\left(\mathrm{NO}_{3}\right)_{2}$ is hydrophilic and fine particulate $\mathrm{Ca}\left(\mathrm{NO}_{3}\right)_{2}$ can deliquescence above $\sim 10 \%$ relative humidity (Tobo et al., 2010). During the dust storm period, the fast formed $\mathrm{Ca}\left(\mathrm{NO}_{3}\right)_{2}$ can form a liquid film on the dust surface, which further promotes formation of nitric acid on the liquid phase by hydrolysis of other nitrogen oxides like $\mathrm{N}_{2} \mathrm{O}_{5}$ (He et al., 2012; Pathak et al., 2009) and adsorption of gaseous $\mathrm{HNO}_{3}$ (Goodman et al., 2000). Such a positive feedback resulted in a significant formation of $\mathrm{NO}_{3}^{-}$even in the dry condition of the dust storm period. In addition, gaseous ammonia is sharply decreased due to the dilution effect of the prevailing winds in the event time. Therefore, the enhanced heterogeneous formation of $\mathrm{NO}_{3}^{-}$and the decreased $\mathrm{NH}_{4}^{+}$led to the urban fine particles more acidic in the event than in the nonevent. However, the prevailing winds in the dust storm time prevented the boundary layer $\mathrm{NO}_{\mathrm{x}}$ from being transported onto the mountain free troposphere, thus $\mathrm{NO}_{3}^{-}$formation was depressed, resulting in the alpine fine particles becoming less acidic when dust was present. Such an increased acidity of airborne particles was also observed in other Chinese mega-cities such as Shanghai (Huang et al., 2010), Beijing and Chongqing (He et al., 2012) in the presence of dust storm.

Inorganic cations/anions ratios of the nonevent fine particles are smaller in Mt. Hua than in Xi' an (0.6 vs. 0.8$)$ (Fig. 10a,b), suggesting that fine particles in Mt. Hua during the non-dust event are more acidic, which is most likely due to increased formation of sulfate during the transport of pollutants from lowland areas to the mountain troposphere. During the nonevent coarse particles showed similar acidic characteristic at both sites; particles in the size of $2.1-5.8 \mu \mathrm{m}$ are slightly acidic or neutral, but particles with a size larger than $5.8 \mu \mathrm{m}$ are basic (Fig. 10c). On the contrary, all the coarse particles in the mountain air were almost neutral during the nonevent and became basic when dust occurred (Fig. 10d). Because $\mathrm{NO}_{3}^{-}, \mathrm{SO}_{4}^{2-}, \mathrm{NH}_{4}^{+}$and $\mathrm{Ca}^{2+}$ are major ions of aerosols at both sites, here we compare their relative abundance to further discuss the acidity difference of aerosols between the urban ground surface and the mountain troposphere (Fig. 11). Equivalent ratio of $\mathrm{NO}_{3}^{-} / \mathrm{SO}_{4}^{2-}$ in fine particles from Xi' an was $0.51 \pm 0.13$ (Fig. 11a) and 0.63 (Fig. 11c) in the nonevent and the event periods, respectively, again demonstrating an enhanced production of $\mathrm{NO}_{3}^{-}$during the dust storm period. Although $\mathrm{NH}_{4}^{+}$relative to the sum of $\left[\mathrm{NO}_{3}^{-}+\mathrm{SO}_{4}^{2-}\right]$ decreased in the event at Mt. Hua, the total abundance of $\mathrm{NH}_{4}^{+}$plus $\mathrm{Ca}^{2+}$ relative to $\left[\mathrm{NO}_{3}^{-}+\mathrm{SO}_{4}^{2-}\right]$ increased in the event (Fig. 11c), being opposite to those in Xi'an. During ageing process $\mathrm{NH}_{4} \mathrm{NO}_{3}$ can be evaporated into the air and decomposed as $\mathrm{NH}_{3}$ and $\mathrm{HNO}_{3}$, while $\mathrm{NH}_{4} \mathrm{HSO}_{4}$ and $\left(\mathrm{NH}_{4}\right)_{2} \mathrm{SO}_{4}$ are chemically stable and enriched in fine particles. The gaseous $\mathrm{HNO}_{3}$ further react with coarse particle and enhances the coarse fractions of $\mathrm{NO}_{3}^{-}$and $\mathrm{Ca}^{2+}$ in the non-dust period (Fig. $11 \mathrm{~b}$ and Table 4). Such a significant segregation of nitrate from sulfate was also observed in the outflow region of East Asia (Sullivian et al., 2007). Nitrate is formed at a faster rate than sulfate and longrange transport of nitrate is less pronounced than that of sulfate. Therefore, $\mathrm{NO}_{3}^{-} / \mathrm{SO}_{4}^{2-}$ in the coarse mode was lower when dust storm occurred especially in the mountainous area (Fig. 11d). $\mathrm{NH}_{4}^{+}, \mathrm{NO}_{3}^{-}$and $\mathrm{SO}_{4}^{2-}$ are the three major ions in fine particle. As shown in Fig. 12, the equivalent ratio of $\left[\mathrm{NO}_{3}^{-}+\mathrm{HSO}_{4}^{2-}\right]$ to $\mathrm{NH}_{4}^{+}$is close to unity, thus it seems plausible that ammonium in the nonevent existed mainly as $\mathrm{NH}_{4} \mathrm{NO}_{3}$ and $\mathrm{NH}_{4} \mathrm{HSO}_{4}$ rather than $\left(\mathrm{NH}_{4}\right)_{2} \mathrm{SO}_{4}$. As discussed above urban fine particles in the event are more acidic, suggesting ammonium in the event was more deficient. The above results suggest that the difference in acidity of particles 

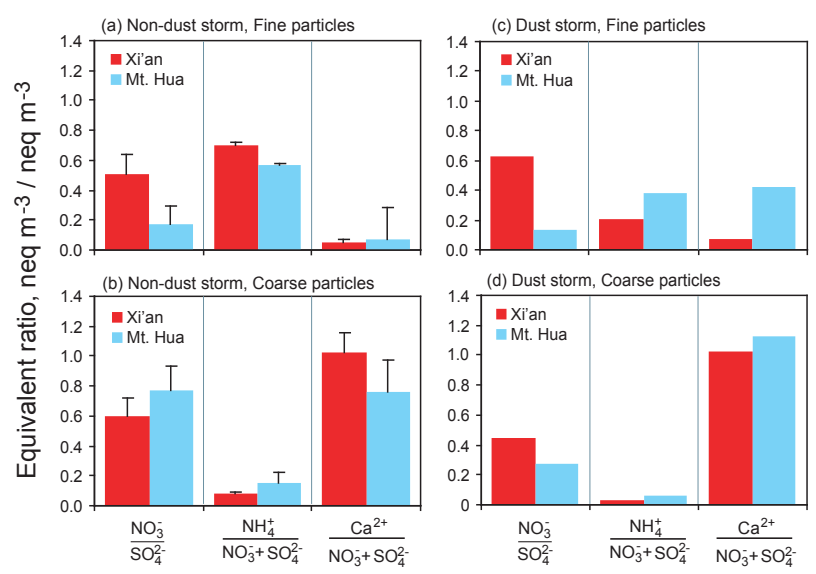

Fig. 11. Equivalent ratios of major inorganic ions in fine $(<2.1 \mu \mathrm{m})$ and coarse $(>2.1 \mu \mathrm{m})$ particles from Xi' an and Mt. Hua during (a, b) non-dust storm and (c, d) dust storm (24 April 2009, DS II) periods.

between the nonevent and the event occurred only in the fine mode.

\section{Summary and conclusion}

Springtime $\mathrm{PM}_{10}$ and size-segregated samples collected in $\mathrm{Xi}$ ' an were determined for EC, OC, WSOC, WSON and inorganic ions, and compared with those simultaneously measured on the mountaintop of Mt. Tai. Particle mass (PM), EC, OC and inorganic ions in Xi' an were 1.8-22 times higher than those in the Mt. Hua air during the non-dust storm period and 1.2-9.2 times higher than those in the mountainous air during the DS II period. High levels of WSON were found in the DS II samples, due to the deposition of anthropogenic WSON onto dust and/or an input of biological organism in Gobi desert dust. Since many known WSON components are highly toxic to humans, a future research on their sources and formation mechanisms is necessary. Compared with those in Xi' an during the nonevent aerosols in the mountaintop free troposphere contains more sulfate and less nitrate, which is due to continuous formation of sulfate during aerosol transport. In the nonevent time sulfate was the most abundant species in aerosols from Xi' an and Mt. Hua, followed by nitrate, $\mathrm{OC}$ and ammonium. On the contrary, $\mathrm{OC}$ became the highest in the event at both sites, followed by $\mathrm{SO}_{4}^{2-}, \mathrm{Ca}^{2+}$ and $\mathrm{NO}_{3}^{-}$, indicating the importance of input of biota in Gobi desert.

In the nonevent time PM showed a similar size distribution between the urban boundary layer and the mountain free troposphere with two equivalent peaks in the fine and coarse modes. In contrast, PM became a unimodal pattern in both regions in the DS II period, dominating in coarse mode. $\mathrm{NH}_{4}^{+}$, $\mathrm{K}^{+}, \mathrm{Mg}^{2+}, \mathrm{Ca}^{2+}, \mathrm{Na}^{2+}$ in Xi' an exhibited similar size distribution patterns to those in the mountain air. $\mathrm{Cl}^{-}$and $\mathrm{NO}_{3}^{-}$
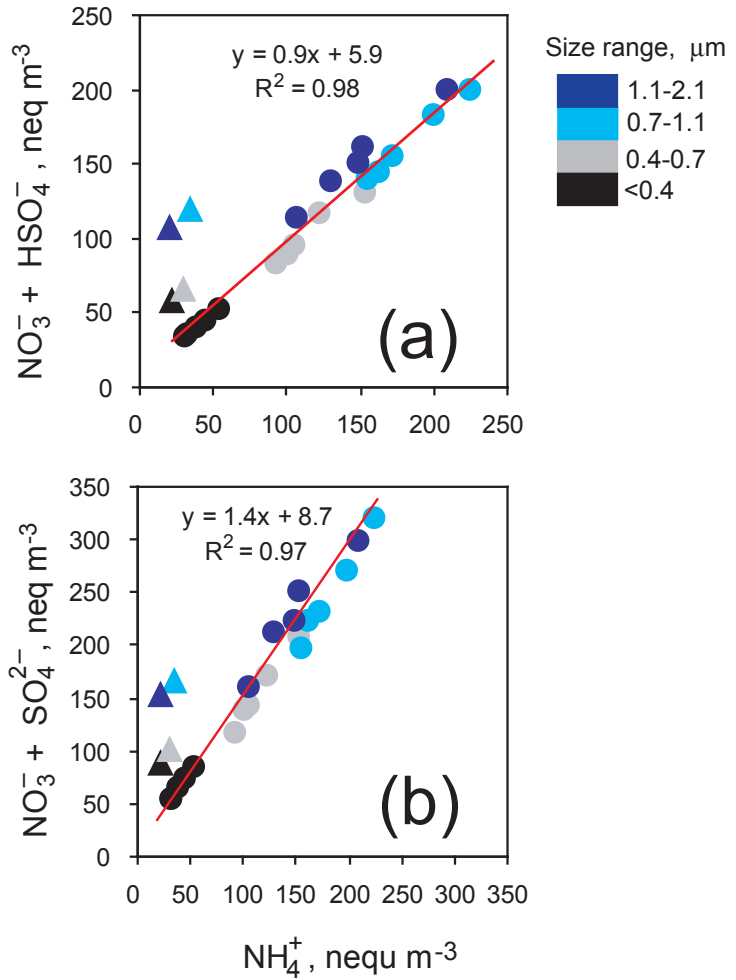

Fig. 12. Linear fit regression for ions in fine particles $(<2.1 \mu \mathrm{m})$ during the non-dust storm (circle symbols) and dust storm (24 April 2009 , triangle symbols) periods in Xi'an.

showed a bimodal pattern on the ground surface and shifted onto large particles in the mountain troposphere during the nonevent period. Such a redistribution was significantly enhanced when dust occurred, resulting in $\mathrm{Cl}^{-}$and $\mathrm{NO}_{3}^{-}$almost entirely staying in the coarse mode in the mountain air.

Compared to those in the nonevent fine particles in the event became more acidic in the urban air and less acidic in the mountain troposphere. The increased acidity in Xi' an is largely ascribed to an enhanced heterogeneous formation of $\mathrm{NO}_{3}^{-}$and a decreased level of $\mathrm{NH}_{3}$ caused by a dilution effect of the prevailing northerly winds in the DS II time. However, such a $\mathrm{NO}_{3}^{-}$formation was depressed in the mountain air in the event, because the prevailing northerly winds prohibited $\mathrm{NO}_{\mathrm{x}}$ from being transported from ground surface to the mountain atmosphere.

Acknowledgements. We thank the three anonymous referees for their comments and suggestion, which are very helpful for improving our paper quality. This work was financially supported by the "Strategic Priority Research Program" of the Chinese Academy of Sciences (Grant No. XDA05100103, XDB05020401) and the Knowledge Innovation Program of Chinese Academy of Sciences (No. KZCX2-YW-148) of Chinese Academy of Sciences.

Edited by: A. B. Guenther 


\section{References}

Agarwal, S., Aggarwal, S. G., Okuzawa, K., and Kawamura, K.: Size distributions of dicarboxylic acids, ketoacids, a-dicarbonyls, sugars, WSOC, OC, EC and inorganic ions in atmospheric particles over Northern Japan: implication for long-range transport of Siberian biomass burning and East Asian polluted aerosols, Atmos. Chem. Phys., 10, 5839-5858, doi:10.5194/acp-10-58392010, 2010.

Altieri, K. E., Hastings, M. G., Peters, A. J., and Sigman, D. M.: Molecular characterization of water soluble organic nitrogen in marine rainwater by ultra-high resolution electrospray ionization mass spectrometry, Atmos. Chem. Phys., 12, 3557-3571, doi:10.5194/acp-12-3557-2012, 2012.

Andreae, M. O., Andreae, T. W., Annegarn, H., Beer, J., Cachier, H., leCanut, P., Elbert, W., Maenhaut, W., Salma, I., Wienhold, F. G., and Zenker, T.: Airborne studies of aerosol emissions from savanna fires in southern Africa: 2. Aerosol chemical composition, J. Geophys. Res., 103, 32119-32128, 1998.

Arimoto, R., Zhang, X. Y., Huebert, B. J., Kang, C. H., Savoie, D. L., Prospero, J. M., Sage, S. K., Schloesslin, C. A., Khaing, H. M., and Oh, S. N.: Chemical composition of atmospheric aerosols from Zhenbeitai, China, and Gosan, South Korea, during ACE-Asia, J. Geophys. Res.-Atmos., 109, D19S04, doi:10.1029/2003JD004323, 2004.

Arimoto, R., Kim, Y. J., Kim, Y. P., Quinn, P. K., Bates, T. S., Anderson, T. L., Gong, S., Uno, I., Chin, M., Huebert, B. J., Clarke, A. D., Shinozuka, Y., Weber, R. J., Anderson, J. R., Guazzotti, S. A., Sullivan, R. C., Sodeman, D. A., Prather, K. A., and Sokolik, I. N.: Characterization of Asian Dust during ACE-Asia, Global Planet. Change, 52, 23-56, 2006.

Brooks, S. D., DeMott, P. J., and Kreidenweis, S. M.: Water uptake by particles containing humic materials and mixtures of humic materials with ammonium sulfate, Atmos. Environ., 38, 18591868, 2004.

Cape, J. N., Cornell, S. E., Jickells, T. D., and Nemitz, E.: Organic nitrogen in the atmosphere - Where does it come from? A review of sources and methods, Atmos. Res., 102, 30-48, 2011.

Chen, H. Y. and Chen, L. D.: Occurrence of water soluble organic nitrogen in aerosols at a coastal area, J. Atmos. Chem., 65, 4971, 2010.

Chow, J. C., Watson, J. G., Chen, L.-W. A., Arnott, W. P., Moosmuller, H., and Fung, K. K.: Equivalence of elemental carbon by thermal/optical reflectance and transmittance with different temperature protocols, Environ. Sci. Technol., 38, 4414-4422, 2004.

Chow, J. C., Watson, J. G., Chen, L.-W. A., Chang, M. C. O., Robinson, N. F., Trimble, D., and Kohl, S.: The IMPROVE temperature protocol for thermal/optical carbon analysis: maintaining consistency with a long-term database, J. Air Waste Manage. Assoc., 57, 1014-1023, 2007.

Dan, M., Zhuang, G., Li, X., Tao, H., and Zhuang, Y.: The characteristics of carbonaceous species and their sources in PM2.5 in Beijng, Atmos. Environ., 38, 3443-3452, 2004.

Dillner, A. M., Schauer, J. J., Zhang, Y., Zeng, L., and Cass, G. R.: Size-resolved particulate matter composition in Beijing during pollution and dust events, J. Geophys. Res., 111, D05203, doi:10.1029/2005JD006400, 2006.

Dinar, E., Mentel, T. F., and Rudich, Y.: The density of humic acids and humic like substances (HULIS) from fresh and aged wood burning and pollution aerosol particles, Atmos. Chem. Phys., 6,
5213-5224, doi:10.5194/acp-6-5213-2006, 2006.

Dunlea, E. J., DeCarlo, P. F., Aiken, A. C., Kimmel, J. R., Peltier, R. E., Weber, R. J., Tomlinson, J., Collins, D. R., Shinozuka, Y., McNaughton, C. S., Howell, S. G., Clarke, A. D., Emmons, L. K., Apel, E. C., Pfister, G. G., van Donkelaar, A., Martin, R. V., Millet, D. B., Heald, C. L., and Jimenez, J. L.: Evolution of Asian aerosols during transpacific transport in INTEX-B, Atmos. Chem. Phys., 9, 7257-7287, doi:10.5194/acp-9-7257-2009, 2009.

Formenti, P., Schütz, L., Balkanski, Y., Desboeufs, K., Ebert, M., Kandler, K., Petzold, A., Scheuvens, D., Weinbruch, S., and Zhang, D.: Recent progress in understanding physical and chemical properties of African and Asian mineral dust, Atmos. Chem. Phys., 11, 8231-8256, doi:10.5194/acp-11-8231-2011, 2011.

Geng, H., Park, Y., Hwang, H., Kang, S., and Ro, C.-U.: Elevated nitrogen-containing particles observed in Asian dust aerosol samples collected at the marine boundary layer of the Bohai Sea and the Yellow Sea, Atmos. Chem. Phys., 9, 6933-6947, doi:10.5194/acp-9-6933-2009, 2009.

Goodman, A. L., Underwood, G. M., and Grassian, V. H.: A laboratory study of the heterogeneous reaction of nitric acid on calcium carbonate particles, J. Geophys. Res., 105, 29053-29064, 2000.

Graham, B., Mayol-Bracero, O. L., Guyon, P., Roberts, G. C., Decesari, S., Facchini, M. C., Artaxo, P., Maenhaut, W., Koll, P., and Andreae, M. O.: Water-soluble organic compounds in biomass burning aerosols over Amazonia - 1. Characterization by NMR and GC-MS, J. Geophys. Res.-Atmos., 107, 8047, doi:10.1029/2001JD000336, 2002.

Griffin, D., Kellogg, C., and Shinn, E.: Dust in the Wind: Long Range Transport of Dust in the Atmosphere and Its Implications for Global Public and Ecosystem Health, Global Change \& Human Health, 2, 20-33, 2001.

Hand, J. L., Malm, W. C., Laskin, A., Day, D., Lee, T., Wang, C., Carrico, C., Carrillo, J., Cowin, J. P., Collett Jr., J., and Iedema, M. J.: Optical, physical, and chemical properties of tar balls observed during the Yosemite Aerosol Characterization Study, J. Geophys. Res.-Atmos., 110, D21210, doi:10.1029/2004JD005728, 2005.

Havers, N., Burba, P., Lambert, J., and Klockow, D.: Characterisation of humic-like substances in airborne particulate matter, J. Atmos. Chem., 29, 45-54, 1998.

He, K., Zhao, Q., Ma, Y., Duan, F., Yang, F., Shi, Z., and Chen, G.: Spatial and seasonal variability of $\mathrm{PM}_{2.5}$ acidity at two Chinese megacities: insights into the formation of secondary inorganic aerosols, Atmos. Chem. Phys., 12, 1377-1395, doi:10.5194/acp12-1377-2012, 2012.

Herner, J. D., Ying, Q., Aw, J., Gao, O., Chang, D. P. Y., and Kleeman, M. J.: Dominant mechanism that shape the airborne particle size and composition distribution in central California, Aerosol Sci. Technol., 40, 827-844, 2006.

Hinds, W. C.: Aerosol Technology: Properties, behavior, and measurement of airborne particles, John Willy \& Sons, New York, 1999.

Huang, K., Zhuang, G., Li, J., Wang, Q., Sun, Y., Lin, Y., and Fu, J. S.: Mixing of Asian dust with pollution aerosol and the transformation of aerosol components during the dust storm over China in spring 2007, J. Geophys. Res.-Atmos., 115, D00K13, doi:10.1029/2009JD013145, 2010. 
Huang, K., Zhuang, G., Lin, Y., Fu, J. S., Wang, Q., Liu, T., Zhang, R., Jiang, Y., Deng, C., Fu, Q., Hsu, N. C., and Cao, B.: Typical types and formation mechanisms of haze in an Eastern Asia megacity, Shanghai, Atmos. Chem. Phys., 12, 105-124, doi:10.5194/acp-12-105-2012, 2012.

Huebert, B. J., Bates, T., Russell, P. B., Shi, G. Y., Kim, Y. J., Kawamura, K., Carmichael, G., and Nakajima, T.: An overview of ACE-Asia: Strategies for quantifying the relationships between Asian aerosols and their climatic impacts, J. Geophys. Res.Atmos., 108, 8663, doi:8610.1029/2003JD003550, 2003.

Ikegami, M., Okada, K., Zaizen, Y., Makino, Y., Jensen, J. B., Gras, J. L., and Harjanto, H.: Very high weight ratios of S/K in individual haze particles over Kalimantan during the 1997 Indonesian forest fires, Atmos. Environ., 35, 4237-4243, 2001.

Jacobson, M. Z.: Global direct radiative forcing due to multicomponent anthropogenic and natural aerosols, J. Geophys. Res.Atmos., 106, 1551-1568, 2001.

Jöckel, P., Brenninkmeijer, C. A. M., and Crutzen, P. J.: A discussion on the determination of atmospheric $\mathrm{OH}$ and its trends, Atmos. Chem. Phys., 3, 107-118, doi:10.5194/acp-3-107-2003, 2003.

Kline, J., Huebert, B., Howell, S., Blomquist, B., Zhuang, J., Bertram, T., and Carrillo, J.: Aerosol composition and size versus altitude measured from the C-130 during ACE-Asia, J. Geophys. Res.-Atmos., 109, D19S08, doi:10.1029/2004JD004540, 2004.

Leaitch, W. R., Macdonald, A. M., Anlauf, K. G., Liu, P. S. K., Toom-Sauntry, D., Li, S.-M., Liggio, J., Hayden, K., Wasey, M. A., Russell, L. M., Takahama, S., Liu, S., van Donkelaar, A., Duck, T., Martin, R. V., Zhang, Q., Sun, Y., McKendry, I., Shantz, N. C., and Cubison, M.: Evidence for Asian dust effects from aerosol plume measurements during INTEXB 2006 near Whistler, BC, Atmos. Chem. Phys., 9, 3523-3546, doi:10.5194/acp-9-3523-2009, 2009.

Li, J., Pósfai, M. L., Hobbs, P. V., and Buseck, P. R.: Individual aerosol particles from biomass burning in southern Africa: 2, Compositions and aging of inorganic particles, J. Geophys. Res., 108, 8484, doi:10.1029/2002JD002310, 2003.

Li, J. J., Wang, G. H., Zhou, B. H., Cheng, C. L., Cao, J. J., Shen, Z. X., and An, Z. S.: Chemical composition and size distribution of wintertime aerosols in the atmosphere of Mt. Hua in central China, Atmos. Environ., 45, 1251-1258, 2011.

Mace, K. A., Duce, R. A., and Tindale, N. W.: Organic nitrogen in rain and aerosol at Cape Grim, Tasmania, Australia, J. Geophys. Res., 108, 4338, doi:10.1029/2002JD003051, 2003a.

Mace, K. A., Artaxo, P., and Duce, R. A.: Water-soluble organic nitrogen in Amazon Basin aerosols during the dry (biomass burning) and wet seasons, J. Geophys. Res., 108, 4512, doi:10.1029/2003JD003557, 2003b.

Mace, K. A., Kubilay, N., and Duce, R. A.: Organic nitrogen in rain and aerosol in the eastern Mediterranean atmosphere: An association with atmospheric dust, J. Geophys. Res.-Atmos., 108, 4320, doi:10.1029/2002JD002997, 2003c.

Manktelow, P. T., Carslaw, K. S., Mann, G. W., and Spracklen, D. V.: The impact of dust on sulfate aerosol, $\mathrm{CN}$ and $\mathrm{CCN}$ during an East Asian dust storm, Atmos. Chem. Phys., 10, 365-382, doi:10.5194/acp-10-365-2010, 2010.

Meng, Z.-Y., Xu, X.-B., Wang, T., Zhang, X.-Y., Yu, X.-L., Wang, S.-F., Lin, W.-L., Chen, Y.-Z., Jiang, Y.-A., and An, X.-Q.: Ambient sulfur dioxide, nitrogen dioxide, and ammonia at ten back- ground and rural sites in China during 2007-2008, Atmos. Environ., 44, 2625-2631, 2010.

McNaughton, C. S., Clarke, A. D., Kapustin, V., Shinozuka, Y., Howell, S. G., Anderson, B. E., Winstead, E., Dibb, J., Scheuer, E., Cohen, R. C., Wooldridge, P., Perring, A., Huey, L. G., Kim, S., Jimenez, J. L., Dunlea, E. J., DeCarlo, P. F., Wennberg, P. O., Crounse, J. D., Weinheimer, A. J., and Flocke, F.: Observations of heterogeneous reactions between Asian pollution and mineral dust over the Eastern North Pacific during INTEX-B, Atmos. Chem. Phys., 9, 8283-8308, doi:10.5194/acp-9-8283-2009, 2009.

Pathak, R. K., Wu, W. S., and Wang, T.: Summertime PM2.5 ionic species in four major cities of China: nitrate formation in an ammonia-deficient atmosphere, Atmos. Chem. Phys., 9, 17111722, doi:10.5194/acp-9-1711-2009, 2009.

Peltier, R. E., Hecobian, A. H., Weber, R. J., Stohl, A., Atlas, E. L., Riemer, D. D., Blake, D. R., Apel, E., Campos, T., and Karl, T.: Investigating the sources and atmospheric processing of fine particles from Asia and the Northwestern United States measured during INTEX B, Atmos. Chem. Phys., 8, 1835-1853, doi:10.5194/acp-8-1835-2008, 2008.

Phadnis, M. J. and Carmichael, G. R.: Numerical investigation of the influence of mineral dust on the tropospheric chemistry of East Asia, J. Atmos. Chem., 36, 285-323, 2000.

Posfai, M., Simonics, R., Li, J., Hobbs, P. V., and Buseck, P. R.: Individual aerosol particles from biomass burning in southern Africa: 1. Composuitions and size distributions of carbonaceous particles, J. Geophys. Res.-Atmos., 103, 8483, doi:10.1029/2002JD002291, 2003.

Qiu, C., Wang, L., Lal, V., Khalizov, A. F., and Zhang, R.: Heterogeneous Reactions of alkylamines with ammonium sulfate and ammonium bisulfate, Environ. Sci. Technol., 45, 4748-4755, 2011.

Ram, K. and Sarin, M. M.: Spatio-temporal variability in atmospheric abundances of EC, OC and WSOC over Northern India, J. Aerosol Sci., 41, 88-98, 2010.

Rodhe, H., Crutzen, P., and Vanderpol, A.: Formation of sulfuric and nitric acid in the atmosphere during long-range transport, Tellus, 33, 132-141, 1981.

Rosenfeld, D., Dai, J., Yu, X., Yao, Z., Xu, X., Yang, X., and Du, C.: Inverse relations between amounts of air pollution and orographic precipitation, Science, 315, 1396-1398, 2007.

Salma, I., Ocskay, R., Chi, X., and Maenhaut, W.: Sampling artefacts, concentration and chemical composition of fine watersoluble organic carbon and humic-like substances in a continental urban atmospheric environment, Atmos. Environ., 41, 41064118, 2007.

Seinfeld, J. H. and Pandis, S. N.: Atmospheric Chemistry and Physics, John Wiley \& Sons, New York, 1998.

Seinfeld, J. H., Carmichael, G. R., Arimoto, R., Conant, W. C., Brechtel, F. J., Bates, T. A., Cahill, T. A., Clarke, A. D., Doherty, S. J., Flatau, P. J., Huebert, B. J., Kim, J., Markowicz, K. M., Quinn, P. K., Russell, L. M., Russell, P. B., Shimizu, A., Shinozuka, Y., Song, C. H., Tang, Y. H., Uno, I., Vogelmann, A. M., Weber, R. J., Woo, J. H., and Zhang, X. Y.: ACEAsia: Regional climatic and atmospheric chemical effects of Asian dust and pollution, B. Am. Meteorol. Soc., 85, 367-380, doi:310.1175/BAMS-1185-1173-1367, 2004.

Shen, Z., Arimoto, R., Cao, J., Zhang, R., Li, X., Du, N., Okuda, T., Nakao, S., and Tanaka, S.: Seasonal Variations and Evidence 
for the Effectiveness of Pollution Controls on Water-Soluble Inorganic Species in Total Suspended Particulates and Fine Particulate Matter from Xi'an, China, J. Air Waste Manage. Assoc., 58, 1560-1570, 2008.

Simoneit, B. R. T., Kobayashi, M., Mochida, M., Kawamura, K., and Huebert, B. J.: Aerosol particles collected on aircraft flights over the northwestern Pacific region during the ACE-Asia campaign: Composition and major sources of the organic compounds, J. Geophys. Res.-Atmos., 109, D19S09, doi:10.1029/2004JD004565, 2004a.

Simoneit, B. R. T., Kobayashi, M., Mochida, M., Kawamura, K., Lee, M., Lim, H. J., Turpin, B. J., and Komazaki, Y.: Composition and major sources of organic compounds of aerosol particulate matter sampled during the ACE-Asia campaign, J. Geophys. Res.-Atmos., 109, D19S10, doi:10.1029/2004JD004598, 2004b.

Sullivan, R. C., Guazzotti, S. A., Sodeman, D. A., and Prather, K. A.: Direct observations of the atmospheric processing of Asian mineral dust, Atmos. Chem. Phys., 7, 1213-1236, doi:10.5194/acp-7-1213-2007, 2007.

Sullivan, R. C., Moore, M. J. K., Petters, M. D., Kreidenweis, S. M., Roberts, G. C., and Prather, K. A.: Effect of chemical mixing state on the hygroscopicity and cloud nucleation properties of calcium mineral dust particles, Atmos. Chem. Phys., 9, 33033316, doi:10.5194/acp-9-3303-2009, 2009a.

Sullivan, R. C., Moore, M. J. K., Petters, M. D., Kreidenweis, S. M., Roberts, G. C., and Prather, K. A.: Timescale for hygroscopic conversion of calcite mineral particles through heterogeneous reaction with nitric acid, Phys. Chem. Chem. Phys., 11, 7826-7837, 2009b.

Sun, Y., Zhuang, G., Huang, K., Li, J., Wang, Q., Wang, Y., Lin, Y., Fu, J. S., Zhang, W., Tang, A., and Zhao, X.: Asian dust over northern China and its impact on the downstream aerosol chemistry in 2004, J. Geophys. Res., 115, D00K09, doi:10.1029/2009jd012757, 2010.

Takahashi, H., Naoe, H., Igarashi, Y., Inomata, Y., and Sugimoto, N.: Aerosol concentrations observed at Mt. Haruna, Japan, in relation to long-range transport of Asian mineral dust aerosols, Atmos. Environ., 44, 4638-4644, 2010.

Tobo, Y., Zhang, D., Matsuki, A., and Iwasaka, Y.: Asian dust particles converted into aqueous droplets under remote marine atmospheric conditions, P. Natl. Acad. Sci. USA, 107, 17905-17910, 2010.

Triendl, R.: Asian states take 'first step' on acid rain, Nature, 392, 426-426, 1998.

van Donkelaar, A., Martin, R. V., Leaitch, W. R., Macdonald, A. M., Walker, T. W., Streets, D. G., Zhang, Q., Dunlea, E. J., Jimenez, J. L., Dibb, J. E., Huey, L. G., Weber, R., and Andreae, M. O.: Analysis of aircraft and satellite measurements from the Intercontinental Chemical Transport Experiment (INTEX-B) to quantify long-range transport of East Asian sulfur to Canada, Atmos. Chem. Phys., 8, 2999-3014, doi:10.5194/acp-8-2999-2008, 2008.

van Donkelaar, A., Martin, R. V., Brauer, M., Kahn, R., Levy, R., Verduzco, C., and Villeneuve, P. J.: Global estimates of ambient fine particulate matter concentrations from satellite-based aerosol optical depth: development and application, Environ. Health Perspect., 118, 8347-8355, 2010.

VanCuren, R. A. and T. A. Cahill: Asian aerosols in North America: Frequency and concentration of fine dust, J. Geophys. Res., 107,
4804, doi:10.1029/2002JD002204, 2002.

Violaki, K. and Mihalopoulos, N.: Water-soluble organic nitrogen (WSON) in size-segregated atmospheric particles over the Eastern Mediterranean, Atmos. Environ., 44, 4339-4345, 2010.

Violaki, K. and Mihalopoulos, N.: Urea: An important piece of Water Soluble Organic Nitrogen (WSON) over the Eastern Mediterranean, Sci. Total Environ., 409, 4796-4801, 2011.

Vrekoussis, M., Kanakidou, M., Mihalopoulos, N., Crutzen, P. J., Lelieveld, J., Perner, D., Berresheim, H., and Baboukas, E.: Role of the $\mathrm{NO}_{3}$ radicals in oxidation processes in the eastern Mediterranean troposphere during the MINOS campaign, Atmos. Chem. Phys., 4, 169-182, doi:10.5194/acp-4-169-2004, 2004.

Vrekoussis, M., Mihalopoulos, N., Gerasopoulos, E., Kanakidou, M., Crutzen, P. J., and Lelieveld, J.: Two-years of $\mathrm{NO}_{3}$ radical observations in the boundary layer over the Eastern Mediterranean, Atmos. Chem. Phys., 7, 315-327, doi:10.5194/acp-7315-2007, 2007.

Wang, G., Kawamura, K., Umemoto, N., Xie, M., Hu, S., and Wang, Z.: Water-soluble organic compounds in PM2.5 and sizesegregated aerosols over Mt. Tai in North China Plain, J. Geophys. Res.-Atmos., 114, D19208, doi:10.1029/2008JD011390, 2009.

Wang, G., Xie, M., Hu, S., Gao, S., Tachibana, E., and Kawamura, K.: Dicarboxylic acids, metals and isotopic compositions of $\mathrm{C}$ and $\mathrm{N}$ in atmospheric aerosols from inland China: implications for dust and coal burning emission and secondary aerosol formation, Atmos. Chem. Phys., 10, 6087-6096, doi:10.5194/acp-106087-2010, 2010.

Wang, G., Kawamura, K., Hu, S., Xie, M., Zhou, B., Li, J., Cao, J., and An, Z.: Selected water-soluble organic compounds found in size-resolved aerosols collected from the urban, mountain, and marine atmospheres over East Asia, Tellus B, 63, 371-381, 2011a.

Wang, G., Chen, C., Li, J., Zhou, B., Xie, M., Hu, S., Kawamura, K., and Chen, Y.: Molecular composition and size distribution of sugars, sugar-alcohols and carboxylic acids in airborne particles during a severe urban haze event caused by wheat straw burning, Atmos. Environ., 45, 2473-2479, $2011 \mathrm{~b}$.

Wang, G., Li, J., Cheng, C., Hu, S., Xie, M., Gao, S., Zhou, B., Dai, W., Cao, J., and An, Z.: Observation of atmospheric aerosols at Mt. Hua and Mt. Tai in central and east China during spring 2009 - Part 1: EC, OC and inorganic ions, Atmos. Chem. Phys., 11, 4221-4235, doi:10.5194/acp-11-4221-2011, 2011c.

Wang, G., Kawamura, K., Cao, J., Zhang, R., Cheng, C., Li, J., Zhang, T., Liu, S., and Zhao, Z.: Molecular distribution and stable carbon isotopic composition of dicarboxylic acids, ketocarboxylic acids and $\alpha$-dicarbonyls in size-resolved atmospheric particles from Xi'an city, China, Environ. Sci. Technol., 46, 4783-4791, 2012a.

Wang, G. H., Kawamura, K., Lee, S. C., Ho, K. F., and Cao, J. J.: Molecular, seasonal and spatial distributions of organic aerosols from fourteen Chinese cities, Environ. Sci. Technol., 40, 46194625, $2006 a$.

Wang, G. H., Kawamura, K., Watanabe, T., Lee, S. C., Ho, K. F., and Cao, J. J.: Heavy loadings and source strengths of organic aerosols in China, Geophys. Res. Lett., 33, L22801, doi:22810.21029/22006GL027624, 2006b.

Wang, G. H., Li, J. J., Cheng, C. L., Zhou, B. H., Xie, M. J., Hu, S. Y., Meng, J. J., Sun, T., Ren, Y. Q., Cao, J. J., Liu, S. X., 
Zhang, T., and Zhao, Z. Z.: Observation of atmospheric aerosols at Mt. Hua and Mt. Tai in central and east China during spring 2009 - Part 2: Impact of dust storm on organic aerosol composition and size distribution, Atmos. Chem. Phys., 12, 4065-4080, doi:10.5194/acp-12-4065-2012, 2012 b.

Yu, J. Z., Yang, H., Zhang, H., and Lau, A. K. H.: Size distributions of water-soluble organic carbon in ambient aerosols and its size-resolved thermal characteristics, Atmos. Environ., 38, 1061-1071, 2004.

Yu, J. Z., Huang, X. F., Xu, J. H., and Hu, M.: When aerosol sulfate goes up, so does oxalate: Implication for the formation mechanisms of oxalate, Environ. Sci. Technol., 39, 128-133, 2005.

Zamora, L. M., Prospero, J. M., and Hansell, D. A.: Organic nitrogen in aerosols and precipitation at Barbados and Miami: Implications regarding sources, transport and deposition to the western subtropical North Atlantic, J. Geophys. Res., 116, D20309, doi:20310.21029/22011JD015660, 2011.
Zhang, D. Z., Zang, J. Y., Shi, G. Y., Iwasaka, Y., Matsuki, A., and Trochkine, D.: Mixture state of individual Asian dust particles at a coastal site of Qingdao, China, Atmos. Environ., 37, 38953901, 2003.

Zhang, Q. and Anastasio, C.: Free and combined amino compounds in atmospheric fine particles (PM2.5) and fog waters from Northern California, Atmos. Environ., 37, 2247-2258, 2003.

Zhang, T., Cao, J. J., Tie, X. X., Shen, Z. X., Liu, S. X., Ding, H., Han, Y. M., Wang, G. H., Ho, K. F., Qiang, J., and Li, W. T.: Water-soluble ions in atmospheric aerosols measured in $\mathrm{Xi}$ 'an, China: Seasonal variations and sources, Atmos. Res., 102, 110119, 2011.

Zhang, Y., Zheng, L., Liu, X., Jickells, T., Neil Cape, J., Goulding, K., Fangmeier, A., and Zhang, F.: Evidence for organic N deposition and its anthropogenic sources in China, Atmos. Environ., 42, 1035-1041, 2008. 